Santa Clara University

Scholar Commons

Accounting

Leavey School of Business

$10-13-2015$

\title{
Is Institutional Ownership Related to Corporate Social Responsibility? The Nonlinear Relation and Its Implication for Stock Return Volatility
}

Maretno Harjoto

Hoje Jo

Yongtae Kim

Santa Clara University, y1kim@scu.edu

Follow this and additional works at: http://scholarcommons.scu.edu/accounting

Part of the Accounting Commons

\section{Recommended Citation}

Harjoto, M., Jo, H., \& Kim, Y. (2015). Is Institutional Ownership Related to Corporate Social Responsibility? The Nonlinear Relation and Its Implication for Stock Return Volatility. Journal of Business Ethics, 1-33. https://doi.org/10.1007/s10551-015-2883-y

The final publication is available at Springer via https:// doi.org/10.1007/s10551-015-2883-y.

This Article is brought to you for free and open access by the Leavey School of Business at Scholar Commons. It has been accepted for inclusion in Accounting by an authorized administrator of Scholar Commons. For more information, please contact rscroggin@scu.edu. 


\title{
Is institutional ownership related to corporate social responsibility? The non-linear relation and its implication for stock return volatility
}

\author{
Maretno Harjoto \\ Associate Professor of Finance \\ Graziadio School of Business and Management \\ Pepperdine University
}

\author{
Hoje Jo \\ Professor of Finance \\ Leavey School of Business \\ Santa Clara University
}

\author{
Yongtae Kim \\ Professor of Accounting \\ Leavey School of Business \\ Santa Clara University
}

\section{Acknowledgement}

Harjoto acknowledges the 2015-2017 Denney Academic Chair from the Denney Endowment, Julian Virtue, Rothschild Endowment, and Funds for Excellence for financial support and release time for this research project. Parts of this paper were completed while Jo was visiting Korea University and Kim was visiting Hong Kong Polytechnic University. 


\title{
Is institutional ownership related to corporate social responsibility? The non-linear relation and its implication for stock return volatility
}

\begin{abstract}
This study examines the relation between corporate social responsibility (CSR) and institutional investor ownership, and the impact of this relation on stock return volatility. We find that institutional ownership does not strictly increase or decrease in CSR; rather, institutional ownership is a concave function of CSR. This evidence suggests that institutional investors do not see CSR as strictly value enhancing activities. Institutional investors adjust their percentage of ownership when CSR activities go beyond the perceived optimal level. Employing the path analysis, we also examine the mediating effect of institutional ownership on the relation between CSR and stock return volatility. We find that CSR decreases stock return volatility at a decreasing rate through its effect on institutional ownership. Our results remain robust under several different CSR measures and estimation methods.
\end{abstract}

Keywords: corporate social responsibility, institutional ownership, stock return volatility, socially responsible investing 


\section{Introduction}

Numerous studies examine the association between corporate social responsibility (CSR) and financial performance. Several review papers note that findings from these studies generally indicate a positive relation between CSR and corporate economic performance, particularly in recent years (Roman et al. 1999; Margolis and Walsh 2001; Orlitzky et al. 2003). However, the direction of causality remains mixed (Margolis et al. 2007). Waddock and Graves (1997) find that corporate social performance is positively associated with prior financial performance but they also find that CSR is positively associated with future financial performance. In contrast, Scholtens (2008) finds that the direction of causality is more likely to run from financial performance to social performance than the other way around. Several recent studies further find that CSR engagement can lower a firm's cost of equity (e.g., Chava 2010; 2014; El Ghoul et al. 2011; Dhaliwal et al. 2011) and cost of debt (e.g., Chava 2014; Goss and Roberts 2011). Merton (1987) and Heinkel et al. (2001) suggest that when socially conscious investors prefer not to include firms with low CSR in their investment portfolio, the expected returns for these excluded firms will increase. Because institutional investors are concerned with their portfolio returns and their shareholdings play a significant role in the capital market, their preference for or against firms that engage in CSR is instrumental to the relation among firms' CSR, cost of capital, and financial performance.

Institutional investors have publicly stated their preference for firms that appear strong on CSR activities. Many institutional investors are signatories to the United Nations' "Principles for Responsible Investment" (UNPRI). ${ }^{1}$ The most recent UNPRI website reports 1,384 investment institutions as signatories, including both public and private pension funds and investment

\footnotetext{
${ }^{1}$ Available at http://www.unpri.org/signatories/signatories/
} 
managers. As of August 2014, these signatories managed assets in excess of $\$ 45$ trillion. $^{2}$ Yet, the U.S. Social Investment Forum (SIF) has estimated that merely $\$ 6.57$ trillion investments are made based on social screenings during 2014. There seems to be a discrepancy between what institutional investors publicly promote and what they actually value.

The main objective of this study is to examine the relation between CSR and institutional ownership and the impact of this relation on stock return volatility. Understanding institutional investors' preferences toward CSR firms is important because institutional ownership influence both equity prices (Gompers and Metrick 2001) and stock return volatility (Bushee and Noe 2000). ${ }^{3}$ Previous studies, however, do not find a robust relation between CSR and institutional ownership (Gillan et al. 2012). We argue that the model that assumes the linear relation between CSR and institutional ownership suffers from model misspecification, which prevents us from obtaining any meaningful relation between CSR and institutional ownership largely due to the non-linear nature of CSR (e.g., Wang et al. 2008).

Consistent with the extent literature, we maintain that there are positive financial payoffs to CSR that is associated with the acquisition of critical resources controlled by stakeholders. These benefits are, however, subject to gradual level off and diminishing returns because CSR benefits cannot continue to increase indefinitely. Recent studies (Flammer 2013; 2015) find evidence suggesting that CSR has decreasing marginal returns. In addition, both direct costs of

\footnotetext{
${ }^{2}$ Canadian institute of chartered accountants, in their 2010 report of Environmental, Social, and Governance (ESG) issues in institutional investor decision making suggest, “... there has been a fundamental shift in consideration of ESG matters in investment decision making. In particular, in the past, trustees may have argued that it was beyond their fiduciary responsibilities to consider ESG matters in an investment decision. Today, it may be considered a breach of fiduciary duty not to consider such matters" (Canadian Institute of Chartered Accountants, 2010).

${ }^{3}$ Institutional ownership also influences accounting conservatism. Ramalingegowda and $\mathrm{Yu}$ (2012), for instance, find that higher ownership by institutions that are likely to monitor managers is associated with more conservative financial reporting, and ownership by monitoring institutions leads to more conservative reporting. Accounting conservatism, however, is not our main focus in this paper.
} 
CSR investment and agency costs arising from managerial incentive of building their own personal reputation using a firm's CSR activities make net benefits from CSR non-linear. Considering countervailing forces simultaneously, Wang et al. (2008) propose an inverse Ushaped relationship between corporate philanthropy and financial performance. Considering a non-linear relation between CSR and financial performance, a non-linear relation between CSR and institutional ownership is quite plausible.

We first investigate how institutional investors perceive CSR activities by examining the relation between standardized CSR scores (CSR index) and institutional ownership. We further examine whether institutions with different level of fiduciary duties perceive investment in CSR differently. Finally, we examine whether institutional ownership mediate the relation between CSR and stock return volatility. Prior studies find an inverse relation between firm risk and CSR (e.g., Spicer 1978; McGuire et al. 1988; Orlitzky and Benjamin 2001; Sharfman and Fernando 2008). Bushee and Noe (2000) find that institutional investor ownership is negatively associated with stock return volatility. To the extent that CSR affects institutional ownership, and stock return volatility is inversely related to institutional ownership, we expect that CSR will affect stock return volatility through its effect on institutional ownership.

Employing firms' CSR activities measured by social ratings from KLD (MSCI ESG) Stats database and standardized by year and industry, we find that institutional ownership is a concave function of CSR. This evidence is consistent with the premise that institutional investors focus on economically optimal value rather than social value of CSR activities. We also find that ownership by banks that have more stringent fiduciary restrictions and investment advisors who have the least fiduciary restrictions are both a concave function of CSR, consistent with Ali et al. (2004) and 
Bushee and Goodman (2007) that these institutions across different fiduciary duties behave similarly to total population of institutional investors.

Using the path analysis, we examine the mediating effect of institutional ownership on the relation between CSR and stock return volatility. We find the negative effect of institutional ownership on stock return volatility, consistent with Bushee and Noe (2000). As the relation between CSR and institutional ownership is concave and the relation between institutional ownership and stock return volatility is negative, we expect the indirect effect of CSR on stock return volatility to be convex. We find the result is consistent with our prediction. The indirect effect of CSR on stock return volatility through its effect on ownership by banks, investment advisors, and pension funds is also convex.

Our results are robust when we examine the effect of two-year lagged measure of CSR, as opposed to one-year lagged measure of CSR, on institutional ownership and stock return volatility. In addition, we find that our results are not driven by the reverse causality. Our results are also consistent in both the level and the change specifications and robust to various subsample periods. We also conduct several robustness tests by including KLD corporate governance criterion into our CSR measure, by separating CSR strengths and concerns, and by using CSR raw scores instead of CSR index. Overall, we find that our results are robust across different specifications.

Our study contributes to existing literature by revealing that the motivation of institutional ownership to invest in stocks of CSR firms is unlikely for social values. Consistent with the premise that institutions focus on the valuation effect of CSR activities and the marginal benefit of CSR diminishes as CSR investment increases (Wang et al. 2008; Kim and Statman 2012), we find that institutional ownership is a concave function of CSR. Our study shows that the weak linear relation between CSR and institutional ownership documented in prior studies is 
due to the non-linear relation between the two. Furthermore, we find that institutional ownership has an important mediating effect for the relation between CSR and firm risk measured by the stock return volatility. To the best of our knowledge, this paper is the first to examine the mediating effect of institutional ownership on the association between CSR and stock return volatility.

The remainder of the paper is organized as follows. In the next section, we briefly review the related literature and discuss research issues. Then, we discuss the sample and measures of CSR and institutional ownership as well as our research design followed by the empirical results section. The final section summarizes our conclusions.

\section{Literature Review and Research Issues}

\section{Relation between CSR activities and institutional investor ownership}

Similar to Mackey et al. (2007), Graff-Zivin and Small (2005), Baron et al. (2011), and Dan and Scholtens (2015), we allow for heterogeneity among investors with respect to their attitude toward CSR. In particular, Graff-Zivin and Small (2005) and Baron et al. (2011) develop the Modigliani-Miller (1958) social market theory to show how CSR is priced in the capital markets under heterogeneous investors. If investors consider firms' socially responsible activities as a perfect substitute for their personal giving, then the capital markets are indifferent between firms with and without CSR. Under heterogeneous investors, however, the markets assign non-zero value for CSR (either positive or negative), leading to the significant effect of CSR on investors' investment decision. As an important part of heterogeneous investors, institutional investors may prefer CSR firms because their constituents want socially responsible investing and are willing to pay a premium for investing in CSR firms to fulfill social objectives beyond their economic objective. 
Empirical studies that examine institutional ownership in CSR firms provide evidence that are fragmented and inconsistent. Hong and Kacperczyk (2009) find that "sin" stocks, i.e., firms operating in the alcohol, tobacco, and gambling industries, are less held by norm-constrained institutions such as pension plans as compared to mutual or hedge funds. Fernando et al. (2010) find that both green firms and toxic firms have lower institutional holdings compared to neutral firms. Harjoto and Jo (2011) find that institutional ownership increases firms' CSR engagement and firms with higher CSR activities and higher institutional ownership tend to have higher financial performance. Chava (2014) finds the negative relation between institutional ownership and a firm's environmental concerns. Dhaliwal et al. (2011) find that dedicated institutions hold shares of firms that initiate CSR disclosure and exhibit better CSR performance. In contrast, a concurrent study by Gillan et al. (2012) finds that institutions hold fewer shares of firms that improve their social and environmental scores.

In general, however, the scope of prior studies is limited by their specific research questions. Hong and Kacperczyk's (2009) analysis is limited to sin stocks that are generally defined by industries in which firms are operating. Fernando et al. (2010) and Chava (2014) limit their investigation to environmental dimension of CSR, and Dhaliwal et al's (2011) findings are conditional on initiation of voluntary CSR disclosure. Gillan et al. (2012) focus on a more general setting but their results are difficult to interpret and it may suffer from a potential modelmisspecification problem since it assumes a linear relation between CSR and institutional ownership.

Since it is institutional investors' fiduciary duty to make investment decisions to generate financial returns for their clients and invest based on their clients' investment preference (Del Guercio 1996), the nature of the relation between CSR and financial performance will play a 
crucial role in determining institutional investors' preferences for investing in socially responsible firms' stocks (Cox et al. 2008). At the same time, institutional investors have come under increasing pressures to encompass CSR initiatives in their investment criteria (Cox et al. 2004). Both of these factors will influence the relation between CSR and institutional ownership.

The extant literature has generally claimed that CSR activities can contribute to higher financial performance by either increasing revenues through enhancing the level of demand for a firm's products or by reducing its price sensitivity (Navarro 1988; McWilliams and Siegel 2000; Sen and Bhattacharya 2001). Additionally, CSR activities can lower production costs either by reducing wages, improving labor productivity, increasing the supply of qualified labor force (Moskowitz 1972; Turban and Greening 1996), or by reducing the level of waste produced in production processes (Porter and van der Linde 1995; Konar and Cohen 2001). However, benefits from CSR cannot increase indefinitely and will gradually level off.

Wang et al. (2008) suggest that total benefit of corporate philanthropy will rise more slowly with each increase in philanthropic contributions. Recent studies provide empirical evidence of decreasing marginal returns from CSR activities. Flammer (2015) examines the effect of CSR on financial performance based on the regression discontinuity design. Specifically, she analyze the effect of CSR-related shareholder proposals that pass or fail by a small margin of votes. She finds that adopting a CSR-related proposal leads to superior financial performance. However, the effect is weaker for companies with higher levels of CSR, suggesting that CSR is a resource with decreasing marginal returns. Flammer (2013) also finds evidence suggesting that environmental CSR has decreasing marginal returns. She finds that the positive (negative) stock market reaction to eco-friendly (eco-harmful) events is smaller for companies 
with higher levels of environmental CSR. These studies strongly suggest a non-linear relation between CSR activities and benefits from such activities.

CSR, by definition, imposes a direct cost on the firm (Barnett and Salomon 2006; Ullmann 1985). These costs often include the diversion of valuable corporate resources such as cash, products, facilities, and human resources devoted to corporate charitable programs (Brammer and Millington 2003; McWilliams and Siegel 2001; Saiia et al. 2003). Each dollar spent to enhance managers' personal goals reduces each dollar return to the institutional investors. Thus, we consider the cost of CSR as a linear upward sloping function.

[Insert Figure 1 here]

When we consider both the benefit and the cost of CSR simultaneously, an inverse U shape (concave) of net benefit emerges as shown in Figure 1. In addition to direct costs associated with CSR investment, the agency theory suggests that managerial discretion in corporate philanthropy may enable managers to use CSR to enhance their own private personal reputations within social circles or to further political or career agendas at the expense of the firm's owners. Wang et al. (2008) consider both direct cost of corporate philanthropy and agency cost of managerial misconduct. Considering countervailing forces simultaneously, Wang et al. (2008) also propose an inverse U-shaped relationship between corporate philanthropy and financial performance.

Despite institutional investors' willingness to support CSR causes, there are limits to the amount and type of resources that these socially conscious institutional investors are able to control and thus potentially provide to the firm. Although socially conscious institutional investors are willing to sacrifice part of their financial wealth to support CSR initiating firms, they nevertheless expect reasonable returns from their financial investments. Within certain limits, CSR helps the firm secure critical resources controlled by various stakeholders and 
provide insurance-like protections (Godfrey 2005) that reduce the firm's exposure to the risk of losing critical resources and therefore increases its value. As a result, institutional investors will increase its shareholdings. However, as CSR increases beyond a sufficiently high level, this positive benefit from CSR will level off. The cost of CSR is increasing in the level of CSR due to direct costs of CSR activities and agency costs. Institutional investors will withdraw their shareholdings as the firm's costs continue to increase. Thus we expect the relationship between CSR and institutional ownership to be concave.

\section{Types of institutional investors and the relation between CSR and institutional ownership}

Institutions of different types could have heterogeneous preferences toward firms CSR activities depending on their fiduciary responsibilities. Institutions are bounded by their fiduciary responsibility to invest funds prudently on behalf of their clients (Del Guercio 1996). Bushee (2001) finds that the level of ownership by institutions with more stringent fiduciary responsibilities is positively associated with the present value of short-term expected earnings and negatively related to the present value of long-term earnings. Differences in the fiduciary responsibilities can influence institutional investors' perception about the value of CSR activities.

Institutions with more stringent fiduciary responsibilities are more sensitive to short-term changes in earnings (Bushee 2001). On the other hand, institutions with more stringent fiduciary obligations face strict and prudent investment standards and invest in a more risk-averse manner (Del Guercio 1996). These institutions tilt their portfolios toward characteristics that would justify the prudence of the investment (Bushee and Goodman 2007). Investments in CSR firms may look more risk-averse and prudent. Therefore, it is an empirical question as to how institutions with more stringent fiduciary responsibilities perceive CSR activities. 


\section{Relation between CSR and stock return volatility}

Several studies report an inverse relation between some measures of firm risk and CSR (e.g., Spicer 1978; McGuire et al. 1988; Orlitzky and Benjamin 2001; Sharfman and Fernando 2008). These studies, however, are silent on the mechanics through which CSR affects firm risk. While dedicated institutions might be interested in firms with stable returns, transient institutions' aggressive trading behavior and propensity to engage in large-scale selling when faced with bad news can lead to higher stock return volatility (Porter 1992). Prior research suggests that changes of institutional ownership are associated with future stock return volatility (Sias 1996; Potter 1992). Moreover, Chan and Lakonishok (1993, 1995) find that both individual trades and packages of trades by institutional investors have sizable price impacts over short horizons, with high turnover institutions producing the largest price impacts.

Bushee and Noe (2000) find a negative correlation between institutional ownership and stock return volatility. While some institutional investors such as hedge funds and pension funds are well positioned to take on risk associated with high stock return volatility, they must pay large expected return premium to get investors to hold risky assets (Cochrane 2001). Furthermore, different trading behavior across institutions may increase or decrease stock return volatility of firms in their investment portfolio. To the extent that institutional ownership is associated with CSR and stock return volatility is affected by institutional ownership, we expect CSR to be related to stock return volatility indirectly through its effect on institutional ownership. If the relation between institutional ownership and stock return volatility is negative and the relation between institutional ownership and CSR is concave, then we expect that the effect of CSR activity on stock return volatility through its impact on institutional ownership will be 
convex. Figure 2 indicates that the indirect relation between stock return volatility and CSR is convex as a result of the concave relation between CSR and institutional ownership (shown in Figure 1). We also expect the indirect effect of CSR on volatility of stock returns through institutional ownership varies across different types of institutions as the relation between CSR and institutional ownership and the relation between institutional ownership and stock return volatility are likely to vary across different types of institutions.

[Insert Figure 2 here]

\section{Sample and Research Design}

\section{Sample descriptions}

We begin with a sample of firms in the Kinder, Lydenberg and Domini's (KLD's) Stats (or MSCI ESG Stats) database from 1991 to 2012. We merge the KLD Stats data with the institutional ownership data from Thomson Reuter's 13F database. Institutional ownership information is drawn from the fourth quarter filings of each calendar year. We utilize the 1991-1993 KLD data to measure the lag effect of firm CSR performance on institutional ownership in $1994 .{ }^{4}$ We obtain firms' financial information from the Compustat database, and stock prices and returns from Center for Research in Security Prices (CRSP) database. After eliminating observations where control variables have missing values, the final sample consists of 13,033 firms-year observations over 1994-2012.

\section{Measures of CSR and institutional ownership}

\footnotetext{
${ }^{4}$ We examine the effect of one-year and two-year lagged CSR on the current year institutional ownership. In addition, to mitigate the problem of low statistical power arising from the stickiness of social scores in KLD data, we measure changes in CSR as changes from year $t-3$ to year $t-1$.
} 
We first calculate the CSR net counts as the number of strengths minus concerns across five non-exclusionary dimensions of CSR: community, diversity, employee, environment, and product. We do not consider exclusionary categories (alcohol, gambling, military contracting, nuclear power, and tobacco) in constructing CSR scores as these dimensions do not pertain to firms' discretionary activities. We exclude human rights criteria since human rights criteria were added to the KLD Stats in 2002. Following Jo and Harjoto (2011) and Kim et al. (2012), we also exclude corporate governance as it is often considered as a distinct construct from CSR. ${ }^{5} \mathrm{We}$ transform CSR net counts to create the CSR index that ranges from 0 to 1 to facilitate comparison of CSR scores across years. ${ }^{6} \mathrm{We}$ use a transformation that preserves the relative distances between the values of CSR net count for firms within the same Fama-French (1997) 48 industries in year t. We normalize CSR net scores by industry and year because important CSR issues, and thus CSR practices, in each industry are different and KLD changes CSR items over the years. Without normalizing CSR net scores, it is difficult to compare CSR scores across industries and years. Our approach is similar to those in Baron et al. (2011) and Jo and Harjoto (2012). Specifically, we construct our CSR index (CSRIDX) based on the following formula:

CSRIDX for firm $i$ in year $t=$

(CSR net count for firm $i$ in year $t-$ Min. CSR net count for firm $i$ ' industry in year $t$ ) (Max. CSR net count for firm $i$ ' industry in year $t$ - Min. CSR net count for firm $i$ ' industry in year $t$ )

\footnotetext{
${ }^{5}$ We conduct a robustness test based on CSR index incorporating governance net counts. Our untabulated results are largely consistent with those based on CSR index excluding governance scores.

${ }^{6}$ We conduct a robustness test based on the CSR raw scores counts rather than CSR index and our untabulated results are largely consistent with those in Tables 4-6.
} 
As we drive our CSR index by normalizing CSR scores with respect to the industry and year, CSR index can be viewed as a firm's CSR performance relative to its peers in the same industry and in the same fiscal year.

We calculate the percentage of all institutional holdings (PCTINSTI) of the firm as the ratio of the sum of shares held by all institutions for each firm to the total shares outstanding. We also classify institutions based on their fiduciary responsibilities (Bushee 2001): banks (BNK), insurance companies (INS), investment banks and independent investment advisers (INVIIA), and pension funds, foundations, endowments, and miscellaneous institutions (MISC). Banks manage equities on behalf of individuals and other institutions through their trust departments. They face strict fiduciary requirements that motivate them to avoid stocks that courts would view as imprudent (Badrinath et al. 1989; Del Guercio 1996). Miscellaneous group includes private pensions, public pensions, and endowments of universities and foundations. This group of institutions also faces fairly strict fiduciary responsibilities, though not so strict as bank trusts (O'Barr and Conley 1992; Del Guercio 1996). Insurance companies hold equities as an investment vehicle for their premiums and manage some private pension funds. In contrast to banks and pensions, these institutions are subject to less restrictive fiduciary constraints. Investment companies and advisers manage individual investments through mutual funds and serve as external fund managers for pensions and endowments. Historically, investment banks and investment advisers have been held to the least restrictive fiduciary responsibilities of any type of institution (Del Guercio 1996).

\section{Research design}

Association between CSR and institutional ownership 
To examine how institutional investors respond to changes in CSR performance, we first consider regressing institutional ownership (PCTINSTI) on the lagged CSR index (CSRIDX) constructed from KLD data along with control variables based on the existing literature.

PCTINSTI $=\alpha_{0}+\alpha_{1} \operatorname{CSRIDX}(t-1)+\sum_{j=2}^{n} \alpha_{j}$ CONTROL VARIABLES $+\varepsilon$

We replace PCTINSTI with ownership by various types of institutions to examine whether different types of institutions perceive CSR activities differently. Appendix A summarizes various institutional ownership and CSR measures.

Our choice of control variables generally follows Del Guercio (1996), Bushee and Noe (2000), Bushee (2001), and Gompers and Metrick (2001). Prior research shows that institutional ownership is associated with factors such as performance, liquidity, risk, and size. Marketadjusted return (MRET) over the past year is included as a control for recent stock performance which is found positively associated with institutional holdings in the prior studies (e.g., Gompers and Metrick 2001). Average monthly trading volume over total shares outstanding (TVOL) is included to control for institutional investors' preference for liquidity. Controlling for performance also helps us to exclude performance as an omitted correlated variable that explains the relation between institutional ownership and CSR.

Proxies for firm idiosyncratic risk include the market model beta $(B E T A)$ as a proxy for systematic risk, the natural logarithm of standard deviation from market model residuals calculated from daily stock returns in a year (IRISK) as a proxy for unsystematic risk, and total debt to total asset ratio (DEBTR) as a measure of bankruptcy risk. Firm size is measured as the natural logarithm of market value of equity (MKTVAL) and included to control for institutional investors preference for larger firms. 
We also include a number of variables to capture changes in fundamental growth and income ratios upon which institutions might base their trading decisions (Bushee and Noe 2001; Gompers and Metrick 2001). These variables include the ratio of earnings (income before extraordinary item) to market value of equity $(E P)$, the book to market value of common equity ratio $(B P)$, the dividend yield $(D P)$, and sales growth $(S A L E G R W)$. An indicator variable for inclusion in the S\&P 500 index (SP500) and the natural log of common shares outstanding (SHROUT) are also added to control for institutional investors' preference toward major stock indices and firms with a large number of shares outstanding. We control for the S\&P stock rating (SPRATING) as a measure of prudence of the investment because some institutions avoid stocks with lower ratings due to fiduciary concerns (Badrinath et al. 1989; Del Guercio 1996). Firm age (FIRMAGE), measured as the number of years since the firm first appears in the CRSP database, is included to control for the prudence of an investment (Del Guercio 1996).

We further control for the previously documented positive relation between earnings performance and institutional ownership (e.g., Del Guercio 1996) by including recent changes in annual earnings per share divided by prior stock price (CEPS). We include the ratio of research and development expense to sales (RNDR) to control for institutions' myopia (Bushee 1998). Appendix B summarizes definitions of control variables.

Estimating equation (1) implies that we assume the linear relation between CSR and institutional ownership. As we discussed earlier, however, this relation may not be linear depending on the institutions' view on firm CSR activities. Wang et al. (2008) find a quadratic relation between corporate social performance (CSP) and financial performance. Fisman et al. (2008) also argue that there is a non-linear relation between CSR and financial performance 
through advertising and product differentiation. Thus, we add a quadratic term to equation (1) to examine a potentially non-linear relation between CSR and institutional ownership.

PCTINSTI $=\alpha_{0}+\alpha_{1} C S R I D X_{-} C(t-1)+\alpha_{2} C S R I D X_{-} C 2(t-1)+\sum_{j=3}^{n} \alpha_{j}$ CONTROL VARIABLES $+\varepsilon$

where CSRIDX_C(t-1) and CSRIDX_C2(t-1) are the centered CSR index and the centered CSR index squared in year $t-1$, where year $t$ is the year that institutional ownership is measured.

Since there is a high correlation between the CSR index and the CSR index squared, we transform our CSR index by subtracting its mean value from each value to mitigate the structural multicollinearity problem in our regression. This method is known as centering the predictor (Rupert 2004). By centering the CSR index, we can also evaluate whether the institutional ownership is increasing or decreasing at the mean value of the CSR index.

\section{Association between CSR and stock return volatility}

Prior studies examine the relation between CSR and firm risk, but are generally mute about the mechanism through which CSR affects firm risk. Because we examine the relation between CSR and institutional ownership, it is of our interest to investigate whether CSR affects firm risk through its effect on institutional ownership. That is, we examine whether institutional ownership mediates the relation between CSR and firm risk.

To examine one consequence of CSR activities attracting institutional investors, we use stock return volatility as a measure of firm risk because Bushee and Noe (2000) show the relation between institutional ownership and stock return volatility. To assess both the direct effect of CSR on stock return volatility and its indirect effect through its effect on institutional ownership, we use the path analysis that can examine the mediating effect of institutional ownership on the relation between CSR and stock return volatility. Path analysis allows us to examine direct and indirect 
effects of CSR on stock return volatility. As prior studies document that stock return volatility decreases in institutional ownership, CSR may affect stock return volatility through its effect on institutional ownership. Alternatively, CSR may have a direct effect on stock return volatility without going through institutional ownership. OLS cannot test the mediating (indirect) effect of CSR on stock return volatility via institutional ownership. ${ }^{7}$ Path analysis, originated from the series of works by Sewall Wright (e.g., Wright 1921, 1923) and applied to a vast array of complex modeling in accounting, econometrics, management, marketing, and sociology literature (Stage et al. 2004), quantifies the direct and indirect effects from the independent variable to the dependent variable. We jointly estimate equation (2) and the following equation to obtain path coefficients. ${ }^{8}$ We then calculate direct and indirect effects based on path coefficients.

$$
\begin{aligned}
\operatorname{DEVRET}(t+1) & =\alpha_{0}+\alpha_{1} \text { PCTINSTI }+\alpha_{2} \text { CSRIDX_C }(t-1)+\alpha_{3} \text { CSRIDX_C2 }(t-1) \\
& +\sum_{j=4}^{n} \alpha_{j} \text { CONTROL VARIABLES }+\varepsilon
\end{aligned}
$$

The dependent variable $(\operatorname{DEVRET}(t+1))$ is the natural logarithm of the one-year ahead standard deviation of daily stock returns over a year's time. Following Bushee and Noe (2000), we include in equation (3) market-adjusted buy-and-hold returns (MRET), the average monthly trading volume (TVOL), the market value of equity (MKTVAL), the debt-to-asset ratio (DEBTR), the EP ratio

\footnotetext{
${ }^{7}$ CSR may affect institutional stock return volatility directly and/or indirectly via its effect on institutional ownership. Path analysis allows us to examine direct and indirect effect separately. While Granger-causation test helps researchers identify a causal relationship, it does not allow researchers to distinguish direct and indirect effects. We provide Granger-causation analysis in Table 8.

${ }^{8}$ Path coefficients are standardized regression coefficients. Because we need to compare effects across equations and between regressors, we need to standardize the effects. While path analysis is useful because it allows researchers to examine direct and indirect effects simultaneously with multiple independent and dependent variables, it cannot establish absolute direction of causality. Path analysis cannot distinguish which of two distinct path diagrams is more correct, nor can it distinguish whether the correlation between $\mathrm{A}$ and $\mathrm{B}$ represents a causal effect of A on B, a causal effect of B on A, mutual dependence on other variables C, D, and so forth (Lea 1997). Despite those limitations, the use of path analysis in social science research has allowed researchers to gain additional understanding and insights into various important issues, and therefore theoretical knowledge on the part of the researcher is critical to the successful application of path analysis (Stage et al. 2004).
} 
$(E P)$, the BP ratio $(B P)$, the dividend-to-equity ratio $(D P)$, sales growth $(S A L E G R W)$, an indicator variable for inclusion in the S\&P 500 index (SP500), S\&P ratings (SPRATING), and the natural log of common shares outstanding (SHROUT) as control variables. Following Bushee and Noe (2000), we measure DEVRET for year $t+1$ and measure institutional ownership and control variables for year $t$. To examine the effect of CSR on institutional ownership and DEVRET, CSR is measured for year $t-1$ (i.e., one-year lag).

The path coefficient (i.e., coefficient standardized by the ratio of the standard deviation of the dependent variable and the standard deviation of the regressor) on CSRIDX_C(t-1) and CSRIDX_C2(t-1) in equation (3) is the direct effect of CSR and CSR squared on stock return volatility. The indirect effect of the CSR and CSR squared on stock return volatility is calculated by the product of the path coefficient on CSRIDX_C(t-1) and CSRIDX_C2(t-1) in equation (2) and the path coefficient on PCTINSTI in equation (3).

[Insert Figure 3 here]

The direct and indirect effects are also depicted by the path diagram in Figure 3. In Figure 3, $a$ is a path coefficient on the centered CSR index (CSRIDX_C(t-1)) in equation (3), $b$ is the path coefficient on the centered CSR index squared (CSRIDX_C2(t-1)) in equation (3), $c$ is the path coefficient on CSRIDX_C(t-1) in equation (2), $d$ is the path coefficient on CSRIDX_C2(t-1) in equation (2), and $e$ is the path coefficient on institutional ownership (PCTINSTI) in equation (3). $a$ is the direct effect of the centered CSR index on stock return volatility, $b$ is the direct effect of the centered CSR index squared on stock return volatility, the product of $c$ and $e$ is the indirect effect of the centered CSR index on stock return volatility through institutional ownership, and the product of $d$ and $e$ is the indirect effect of the centered CSR squared on stock return volatility through institutional ownership. 


\section{Descriptive statistics}

Table 1 presents the sample distribution across 48 industries based on Fama and French (1997) industry classifications. Financial institutions and utilities represent substantial portions of the sample. ${ }^{9}$ The average percentage of institutional shareholdings (PCTINSTI) for firms in the sample is between $53 \%$ and $85 \%$ for all industries. This indicates that the institutional holders represent the majority of firms' shareholders. Therefore, this study examines the relation (if any) between CSR and the shareholders who hold the large block or majority of firms' stock. The average CSR index of the firms is between 0.28 and 0.66 indicating that there are wide variations of CSR activities across different industries even after standardizing the CSR index for each industry and each year.

[Insert Table 1 here]

Panel A of Table 2 provides descriptive statistics. We winsorize all continuous variables at $1 \%$ and $99 \%$ of the distribution. ${ }^{10}$ Average $\operatorname{CSRIDX}(t-1)$ is less than 0.5 indicating a relatively small number of observations with high CSR scores. The average institutional ownership (PCTINSTI) is $70 \%$. Independent investment advisers (INVIIA) have the higher percentage ownership relative to insurance companies (INS).

[Insert Table 2 here]

Descriptive statistics for control variables are also reported in Table 2. The average beta $(B E T A)$ is 1.14 which indicates that firms in the sample are slightly riskier than the market portfolio. Sample firms have average total debt ratio $(D E B T R)$ of $20.5 \%$ and book to market value $(B P)$ of 0.51 . The average dividend payout ratio $(D P)$ is $1.71 \%$ and firms' average sales

\footnotetext{
${ }^{9}$ We conduct a robustness test by excluding financial and utility firms and find qualitatively similar results.

${ }^{10}$ The results without winsorization are qualitatively similar.
} 
growth is $8.68 \%$. Approximately $49 \%$ of the firms are listed in the Standard and Poor's 500 (S\&P500) Index and average firm age (FIRMAGE) is about 28 years. The minimum firm age is 3.47 years and the maximum is 83.86 years indicating that the sample includes both young and mature firms.

We report mean institutional ownership across quintiles of CSRIDX(t-1) in Panel B of Table 2. As shown, mean institutional ownership (PCTINSTI) increases from the lowest quintile to the $2^{\text {nd }}$ quintile, but decreases afterwards. Ownership by investment banks and independent investment advisers (INVIIA) shows the same pattern. Ownership by banks $(B N K)$ increases from the lowest quintile to the $4^{\text {th }}$ quintile, but decreases afterwards. Ownership by miscellaneous institutions (MISC) shows a similar pattern. Ownership by insurance companies (INS), however,

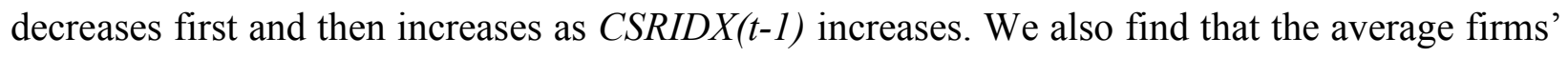
value, measured by the mean of firms' Tobin Q (TOBINQ) increases from the lowest CSR quintile to the $3^{\text {rd }}$ quintile but then decreases after the $3^{\text {rd }}$ quintile indicating a concave relation between firm value and CSR. We find that the one-year ahead natural logarithmic of average standard deviation of daily stock returns (DEVRET) decreases initially up to the $3^{\text {rd }}$ quintile and then increases afterward indicating a convex relation between stock return volatility and CSR. The results in Panel B of Table 2 justify the examination of the non-linear relation between institutional ownership and firms' CSR in our regression model. Given the different patterns of the relation between CSRIDX and ownership by different types of institutional investors, it is also important to examine various types of institutions separately.

[Insert Table 3 here] 
Table 3 presents the Pearson correlations among control variables. Most of the correlation coefficients among control variables are no more than $50 \%$, mitigating concerns for multicollinearity.

\section{Empirical Results}

\section{Relation between institutional investor ownership and CSR}

We first examine the impact of CSR on institutional ownership assuming the linear relation between the two. Then, we regress institutional ownership on the centered CSR index and the centered CSR index squared considering a possible non-linear relation between institutional investor ownership and CSR performance. All regression analyses include Fama and French (1997) 48 industry dummies and year dummies. The t-statistics are estimated based on standard errors clustered by the firm level.

Table 4 presents the results. The results in the first column show that when the relation is restricted to be linear, the overall impact of CSR on institutional ownership is statistically insignificant. This insignificant finding is consistent with existing studies (Dhaliwal et al. 2011; Gillan et al. 2012). More importantly, this finding implies that the relation between CSR and institutional ownership might be neither strictly positive nor strictly negative.

[Insert Table 4 here]

Thus, we examine the quadratic relation between ownership by institutions and the centered CSR index and CSR index squared. The second column of Table 4 shows the negative but statistically insignificant coefficient on the centered CSR index and the negative and statistically significant coefficient on the centered CSR index squared (CSRIDX_C2(t-1)). This result suggests that there is a concave relation between institutional ownership and CSR, which 
is consistent with our prediction. The insignificant coefficient on the centered CSR index $\left(C S R I D X_{-} C(t-1)\right)$ implies that the maximum level of institutional ownership is approximately at the mean level of CSR performance and as the firms' increase CSR beyond its current mean, institutional ownership starts to decline. Overall, our empirical results demonstrate that institutional investors adjust their shareholdings according to their value-maximizing view and consider that beyond the optimal level, additional CSR investment is value reducing activities.

Next, we examine the impact of CSR across different types of institutional investors based on their fiduciary responsibilities and report the results in Table 5. We find that the relations between CSR and institutional ownership across different types are generally insignificant.

[Insert Table 5 here]

The quadratic relation between CSR and institutional ownership across different level of fiduciary responsibilities shows that there is a concave relation between CSR activities and ownership by banks $(B N K)$ which is considered to have the most restrictive fiduciary responsibilities and the investment banks and independent investment advisers (INVIIA) which is considered to have the least restrictive fiduciary duties. The relations between CSR and ownership by insurance companies and miscellaneous institutions are also concave. ${ }^{11}$ This evidence indicates that the relation between CSR and institutional ownership does not vary across different levels of fiduciary obligations.

The coefficients on the control variables are generally consistent with Bushee (2001). We find that market adjusted returns (MRET) positively affect ownership by insurance companies

\footnotetext{
${ }^{11}$ The level of institutional ownership may be correlated with the lagged level of institutional ownership. We include the lagged level of institutional ownership at the beginning of the year as an additional control variable in the regressions and rerun our analyses. Our untabulated results are largely consistent with those in Tables 4-6.
} 
(INS) and independent investment advisers (INVIIA) but adversely affect ownership by pension funds and foundations (MISC), which are consistent with Bushee (2001). The market value of equity $(M K T V A L)$ positively affects almost all types of institutional investors.

Firm's performance is always a potential omitted variable in any CSR study. In our case, better performing firms can afford CSR and institutions may hold larger ownership of these

firms. To address the endogeneity problem, we have included various performance-related controls, including market-adjusted buy-and-hold returns (MRET), natural logarithm of market value of common equity (MKTVAL), the ratio of income before extraordinary item to market value of common equity $(E P)$, changes in annual earnings per share deflated by prior stock price (CEPS), and sales growth (SALEGRW), in our regressions.

\section{Association between CSR and stock return volatility}

In the previous section, we show that there is a quadratic relation between CSR and institutional ownership, indicating that institutional investors focus on value maximization. Given that firms stock return volatility is inversely related to institutional ownership (Bushee and Noe 2000; Gompers and Metrick 2001), we expect that there is also a non-linear relation between CSR and stock return volatility. We examine the non-linear effect of CSR on stock return volatility directly and indirectly through its effect on institutional ownership.

To assess and compare direct and indirect effect of CSR on stock return volatility, we conduct the path analysis similar to Bushee and Noe (2000). We jointly estimate two regressions, equations (2) and (3). In the first equation, we regress institutional ownership on the centered CSR index, the centered CSR index squared, and control variables. In the second equation, we regress stock return volatility on institutional ownership, the centered CSR index and the 
centered CSR index squared, and control variables. Path coefficients are calculated by standardizing regression coefficients in two equations and the direct and indirect effects are determined based on path coefficients. If the relation between CSR and institutional ownership is concave and institutional ownership and stock return volatility are negatively associated, the indirect effect of CSR on stock return volatility will be convex. In other words, increases in CSR indirectly reduce firm risk through institutional ownership up to a point at which institutional investors view CSR activities as optimal. We present the results from estimating equation (3) in Panel A of Table 6 and summarize the direct and indirect effect of CSR on stock return volatility in Panel B of Table $6 .^{12}$

[Insert Table 6 here]

As shown in the first column in Panel A of Table 6, on average institutional ownership (PCTINSTI) is inversely related to stock return volatility. The results for ownership by various types of institutions based on their investment horizons and fiduciary responsibilities are shown in the second column. We find that ownership by banks $(B N K)$, independent investment advisers (INVIIA), and pension funds, foundations, and miscellaneous institutions (MISC) are negatively associated with stock return volatility. Banks have the highest fiduciary restrictions and independent investment advisers have the least restrictive fiduciary duties. Thus the results suggest that the extent of fiduciary obligations does not affect the relation between institutional ownership and stock return volatility. The coefficient on CSRIDX_C(t-1) and the coefficient on CSRIDX_C2(t-1) are insignificant, suggesting that after controlling for institutional ownership, there is no direct impact of one-year lag CSR activities on firm risk.

\footnotetext{
${ }^{12}$ Statistical significance for the indirect effect in Panel B is determined based on statistical significance of the path coefficient on centered CSR index (CSRIDX_C $(t-1))$ and centered CSR index squared (CSRIDX_C2(t-1)) in the first regression and statistical significance of the path coefficient on institutional ownership in the second regression. We take the lesser of the two statistical significance levels.
} 
As shown in Panel B of Table 6, we find a significant indirect effect of CSR on stock return volatility through its effect on institutional ownership. Focusing on the overall institutional ownership (PCTINSTI), we find that the indirect effect of the centered CSR index squared $\left(C S R I D X_{-} C 2(t-1)\right)$ on stock return volatility is positive and statistically significant, while the indirect effect of the centered CSR index $\left(C S R I D X_{-} C(t-1)\right)$ is insignificant. The significantly positive indirect effect of CSRIDX_C2(t-1) suggests that the indirect relation between CSR on stock return volatility is convex, consistent with our prediction that CSR reduces firm risk indirectly through institutional ownership up to a point where institutional investors view CSR as still value maximizing activities.

When we examine the indirect effect of CSR on stock return volatility through ownership by institutions with different level of fiduciary responsibilities, we find that the indirect effects through ownership by banks $(B N K)$, investment bank and independent investment advisers (INVIIA), and pension funds, foundations, and miscellaneous institutions (MISC) are similar to that through the overall institutional ownership. Overall, we find evidence that CSR activities affect stock return volatility through its effect on institutional ownership.

\section{Two-year lag and causality of the relation}

Thus far, we examine the relation between institutional ownership and one-year lagged CSR in order to examine the effect of CSR activities on institutional ownership. Considering the delayed effect of CSR on institutional ownership and stock return volatility, we also use twoyear lagged CSR variables. We report the result in Table 7. We summarize the effect of CSR on the aggregated institutional ownership in Panel A, the effect of CSR across different types of institutional investors in Panel B, the result from regressing stock return volatility on institutional 
ownership and CSR in Panel C, and the direct and indirect effect of CSR on stock return volatility in Panel D. The results are qualitatively the same as those in Tables 4-6 except that we find strong positive direct effect of two-year lag CSR on stock return volatility.

[Insert Table 7 here]

Reverse causality is a potential concern. While firms with high CSR ratings might attract institutional investors, institutional investors might well encourage managers to increase CSR for legitimacy concerns. Dam and Scholtens $(2012,2013)$, for example, suggest that with large shareholders, CSR need to be included in their performance assessment. To examine this potential reverse causality, we regress CSR on one-year or two-year lagged institutional ownership and report the results in Panel A of Table 8. We find that lagged institutional ownership does not affect CSR ratings. We also regress one-year ahead institutional ownership on lagged stock return volatility after controlling for lagged CSR ratings in order to examine the potential reverse causality between institutional ownership and stock return volatility. The results are reported in Panel B of Table 8. Again, we find no evidence that lagged stock return volatility affects institutional ownership. Therefore, it is unlikely that our results in Tables 4-7 are driven by the reverse causality.

[Insert Table 8 here]

\section{Change on change analysis}

Finally, we examine whether changes in CSR ratings lead to changes in institutional ownership and changes in stock return volatility. Because CSR ratings in KLD Stats tend to be sticky, using a change specification may reduce the statistical power. To mitigate this problem, similar to Dam and Scholtens (2012), Harjoto and Jo (2011), and Jo and Harjoto (2011, 2012), 
we use changes in changes analysis, but we take changes in changes over two years, i.e., from year $t-3$ to year $t-1$. Table 9 reports the results from the change specifications. We summarize the effect of changes in CSR on changes in institutional ownership in Panel A, the effect of changes in institutional ownership and changes in CSR on changes in stock return volatility in Panel B, and the direct and indirect effect of changes in CSR on changes in stock return volatility in Panel C. The tenor of the results is the same as that from the level specification reported in Tables 4-6. That is, the relation between changes in institutional ownership and changes in CSR ratings is concave, changes in institutional ownership is negatively related to changes in institutional ownership, and the indirect effect of changes in CSR on changes in stock return volatility through changes in institutional ownership is convex. ${ }^{13}$

[Insert Table 9 here]

We also find that an increase in ownership by banks $(B N K)$, investment bank and independent investment advisers (INVIIA), and pension funds, foundations, and miscellaneous institutions (MISC) decreases stock return volatility. The direct effect of changes in CSR ratings on changes in stock return volatility is statistically insignificant across all models.

\section{The interactions between CSR and institutional ownership on stock return volatility}

In this section, we examine the relation between CSR, institutional ownership, stock return volatility by including the interaction of CSR and institutional ownership in OLS regressions. The interaction terms allow us to evaluate the effect of CSR on the relation between institutional ownership and stock return volatility and the effect of institutional ownership on the

\footnotetext{
${ }^{13}$ We find that unlike in the level specification, the direct effect of changes in CSR on changes in stock return volatility is not statistically significant. It appears that the positive relation between the two-year lag of CSR level and the level of stock return volatility in Table 7 is only transitory (static) and therefore does not hold in the change specification.
} 
relation between CSR and stock return volatility. However, including interaction terms in regressions cannot help us to understand potential direct and indirect effects of CSR on stock return volatility. Thus interaction terms and path analysis provide different insights on the relation between CSR and stock return volatility. The results tabulated in Table 10 suggest that the coefficients on the interaction terms between CSR and institutional ownerships are generally insignificant in both the level specification (Panel A) and the change specification (Panel B).

[Insert Table 10 here]

\section{Robustness tests}

We conduct additional analyses to check the robustness of our results. In the wake of corporate scandals and financial crisis, corporate governance has become important issues that are well aligned with public perception of corporate social responsibility. Thus, in our first robustness test, we include the MSCI ESG (KLD) corporate governance criterion in our CSR index measure. Untabulated results from including KLD corporate governance criterion as a part of CSR measure are consistent with our main results.

Chatterji et al. (2009) indicate that the construct of CSR strengths and concerns ratings in the KLD database represent different measures of firms' social performance and transparency of management practices. We re-estimate our models by separating the CSR strengths and concerns indices and examine the impact of CSR strengths and concerns indices on institutional ownership and stock return volatility. Untabulated results suggest that our results are largely driven by CSR strengths.

Last but not least, we examine the impact of raw CSR counts (scores) instead of CSR index. Untabulated results from using raw CSR scores are generally weaker than the CSR index, potentially reflecting the problem that raw CSR scores are not comparable across industries and 
years. Although raw CSR scores are not significantly associated with total institutional ownership, the results based on institution types are largely consistent with those tabulated in the paper. For example, the relation between CSR and bank ownership is concave. The results based on change specifications are also similar to those tabulated in the paper.

\section{Conclusions}

Recent public statements by institutional investors indicate that their investment preferences are now tilted toward investment in CSR firms' equities. However, anecdotal evidence suggests that they may not practice what they publicly promote. In this study, we examine the non-linear relation between institutional ownership and CSR activities. In addition, we investigate the impact of firms' CSR activities on institutional ownership across different types of institutions. We further examine whether the relation between CSR and institutional ownership has any implication on stock return volatility.

Given that the CSR investment is subject to a diminishing marginal return and the increasing cost of CSR, we predict the relation between institutional ownership and CSR to be concave. We find empirical evidence consistent with this prediction. This evidence casts doubt on the notion that institutional investors invest in CSR firms because they consider social values as a priority of their investment decision. We find that both banks, institutions with the most restrictive fiduciary responsibilities, and investment banks and independent investment advisers, institutions with the least restrictive fiduciary duties, behave as if the net benefit of CSR decreases as CSR increases. This implies that the relation between CSR and institutional ownership does not vary across different levels of fiduciary responsibility. 
We also examine the impact of CSR on firm risk, measured by stock return volatility, indirectly through its effect on institutional ownership. Given the concave relation between CSR and institutional ownership and negative relation between institutional ownership and firm risk (Bushee and Noe 2000), we expect that the relation between CSR and firm risk through institutional ownership to be convex. Using the path analysis, we show that increases in CSR reduce stock return volatility at a decreasing rate through its effect on institutional ownership. Our results indicate that CSR reduces firm risk indirectly through institutional ownership up to a point at which institutional investors view CSR as optimal. 


\section{References}

Ali, A., Durtschi, C., Lev, B., \& Trombley, M. (2004). Changes in institutional ownership and subsequent earnings announcement abnormal returns. Journal of Accounting, Auditing, and Finance, 19, 221-248.

Badrinath, S., Gay, G., \& Kale, J. (1989). Patterns of institutional investment, prudence and the managerial safety net hypotheses. Journal of Risk and Insurance, 56, 605-629.

Barnett, M. L., \& Salomon, R. M. (2006). Beyond dichotomy: The curvilinear relationship between social responsibility and financial performance. Strategic Management Journal, 27, 1101-1122.

Baron, D., Harjoto, M., \& Jo, H. (2011). The economics and politics of corporate social performance. Business and Politics, 13, 1-46.

Brammer, S., \& Millington, A. (2003). The effect of stakeholder preferences, organizational structure and industry type on corporate community involvement. Journal of Business Ethics, 45, 213-226.

Bushee, B. (1998). The influence of institutional investors on myopic R\&D investment behavior. The Accounting Review, 73, 305-333.

Bushee, B. (2001). Do institutional investors prefer near-term earnings over long-run value? Contemporary of Accounting Research, 18, 207-246.

Bushee, B., \& Noe, C. (2000). Corporate disclosure practices, institutional investors, and stock return volatility. Journal of Accounting Research, 38 (Supplement), 171-202.

Bushee, B., \& Goodman, T. (2007). Which institutional investors trade based on private information about earnings and returns? Journal of Accounting Research, 45, 289-321.

Campbell, J. L. (2007). Why would corporations behave in socially responsible ways? An institutional theory of corporate social responsibility. Academy of Management Review, 32, 946-967.

Canadian Institute of Chartered Accountants. (2010). Environmental, social, and governance (ESG) issues in institutional investor decision making, Toronto, Ontario, Canada.

Chava. S. (2010). Socially responsible investing and expected stock returns. Working Paper. Georgia Institute of Technology. Available at http://www.q-group.org/wp-content/uploads /2014/01/Chava SRI v2.pdf

Chava. S. (2014). Environmental externalities and cost of capital. Management Science, forthcoming. http://dx.doi.org/10.1287/mnsc.2013.1863

Chan, 1. K. C., \& Lakonishok, J. (1993). Institutional trades and intraday stock price behavior. Journal of Financial Economics, 33, 173-200.

Chan, 1. K. C., \& Lakonishok, J. (1995). The behavior of stock prices around institutional trades. Journal of Finance, 50, 1147-74.

Chatterji, A.K., Levine, D.I., \& Toffel, M.W. (2009). How well do social ratings actually measure corporate social responsibility? Journal of Economics \& Management Strategy 18(1), $125-$ 169. 
Cochrane, J.H. (2001). Asset Pricing. Princeton University Press, Princeton, NJ.

Cox, P., Brammer, S., \& Millington, A. (2004). An empirical examination of institutional investor preferences for corporate social performance. Journal of Business Ethics, 52, 2743.

Cox, P., Brammer, S., \& Millington, A. (2008). Pension funds and corporate social performance. An empirical analysis. Business \& Society, 47, 213-241.

Cox, P., \& Schneider, M. (2010). Is corporate social performance a criterion in the overseas investment strategy of U.S. pension plans? Business \& Society, 49, 252-289.

Cox, P., \& Wicks, P. (2011). Institutional interest in corporate responsibility: Portfolio evidence and ethical explanation. Journal of Business Ethics, 103, 143-165.

Dam, L., \& Scholtens, B. (2012). Does ownership type matter for corporate social responsibility? Corporate Governance: An International Review, 20, 233-252.

Dam, L., \& Scholtens, B. (2013). Ownership concentration and CSR policy of European multinational enterprises. Journal of Business Ethics, 118, 117-126.

Dam, L., \& Scholtens, B. (2015). Toward a theory of responsible investing: On the economic foundations of corporate social responsibility. Resource and Energy Economics, 41, 103121.

Del Guercio, D. (1996). The distorting effect of the prudent-man laws on institutional equity investments. Journal of Financial Economics, 40, 31-62.

Dhaliwal, D., Li, O., Zhang, A., \& Yang, Y. (2011). Voluntary nonfinancial disclosure and the cost of equity capital: The initiations of corporate social responsibility reporting. The Accounting Review, 86, 59-100.

El Ghoul, S., Guedhami, O., Kwok, C., \& Mishra, D. (2011). Does corporate social responsibility affect the cost of capital? Journal of Banking and Finance, 35, 2388-2406.

Fama, E., \& French, K. (1997). Industry costs of equity. Journal of Financial Economics, 43, 153-197.

Fernando, C., Sharfman, M., \& Uysal, V. (2010). Does greenness matter? The effect of corporate environmental performance on ownership structure, analyst coverage, and firm value. Working Paper. Available at http://www.fma.org/NY/Papers/Environmental_Performance OU FMA.pdf

Fisman, R., Heal, G., \& Nair, V.B. (2008). A model of corporate philanthropy, Working Paper, Columbia University and University of Pennsylvania.

Flammer, C. (2013). Corporate social responsibility and shareholder reaction: The environmental awareness of investors. Academy of Management Journal, 56(3), 758-781.

Flammer, C. (2015). Does corporate social responsibility lead to superior financial performance? A regression discontinuity approach. Management Science (in press).

Gillan, S., Hartzell, J., Koch, A., \& Starks, L. (2012). Firms' environmental, social and governance (ESG) choices, performance and managerial motivation. Working Paper. Available at http://www.business.pitt.edu/faculty/papers/koch3.pdf 
Godfrey, P. C. (2005). The relationship between corporate philanthropy and shareholder wealth: A risk management perspective. Academy of Management Review, 30, 777-798.

Gompers, P., \& Metrick, A. (2001). Institutional investors and equity prices. Quarterly Journal of Economics, 116, 229-259.

Goss, A., \& Roberts, G. (2011). The impact of corporate social responsibility on the cost of bank loan. Journal of Banking and Finance, 35, 1794-1810.

Graff-Zivin, J., \& Small, A. (2005). A Modigliani-Miller theory of altruistic corporate social responsibility. Topics in Economic Analysis \& Policy, 5, Article 10.

Harjoto, M., \& Jo, H. (2011). Corporate governance and CSR nexus. Journal of Business Ethics, $100(1), 45-67$

Heinkel, R., Kraus, A., \& Zechner, J. (2001). The effect of green investment on corporate behavior. Journal of Financial and Quantitative Analysis, 36, 431-449

Hong, H., \& Kacperczyk, M. (2009). The price of sin: The effect of social norms on markets. Journal of Financial Economics, 93, 15-36.

Ioannou, I., \& Serafeim, J. (2014). The impact of corporate social responsibility on investment recommendations: Analysts' perceptions and shifting institutional logics. Strategic Management Journal, doi: 10.1002/smj.2268

Jo, H., \& Harjoto, M. (2011). Corporate governance and firm value: The impact of corporate social responsibility. Journal of Business Ethics, 103(3), 351-383.

Jo, H., \& Harjoto, M. (2012). The causal effect of corporate governance and corporate social responsibility. Journal of Business Ethics, 106(1), 53-72.

Kim, Y., \& Statman, M. (2012). Do corporations invest enough in environmental responsibility? Journal of Business Ethics, 105, 115-129

Kim, Y., Park, M., \& Wier, B. (2012). Is earnings quality associated with corporate social responsibility? The Accounting Review, 87, 761-796.

Konar, S., \& Cohen, M. (2001). Does the market value environmental performance? Review of Economics and Statistics, 83, 281-289.

Lea, S. (1997). Path analysis. University of Exeter. From http://www.ex.ac.uk/ SEGLea/multvar2/ oldwelcome.html

Mackey, A., Mackey, T., \& Barney, J. (2007). Corporate social responsibility and firm performance: Investor preferences and corporate strategies. Academy of Management Review, 32, 817-835.

Margolis, J.D., Elfenbein, H.A., \& Walsh, J. P. (2007). Does it pay to be good? A meta analysis and redirection of research on the relationship between corporate social and financial performance," Working paper. Harvard Business School. Available at: http://stakeholder. bu.edu/Docs/Walsh,\%20Jim\%20Does\%20It\%20Pay\%20to\%20Be\%20Good.pdf

Margolis, J. D., \& Walsh, J. P. (2001). People and profits? The search for a link between a company's social and financial performance. Mahwah, NJ, Lawrence Erlbaum Associates.

McGuire, J.B., Sundgren, A., \& Schneeweis, T. (1988). Corporate social responsibility and firm financial performance. Academy of Management Journal, 31, 854-872. 
McWilliams, A., \& Siegel, D., (2000). Corporate social responsibility and financial performance: correlation or misspecification? Strategic Management Journal, 21, 603-609.

McWilliams, A., \& Siegel, D. (2001). Corporate social responsibility: A theory of the firm perspective. Academy of Management Review, 26, 117-127.

Merton, R. (1987). A simple model of capital market equilibrium with incomplete information. Journal of Finance, 42, 483-510.

Modigliani, F., \& Miller, M.H. (1958). The cost of capital, corporation finance and the theory of investment. American Economic Review, 48, 261-297.

Moskowitz, M. (1972). Choosing socially responsive stocks. Business and Society Review, 10, $71-75$.

Navarro, P. (1988). Why do corporations give to charity?” Journal of Business, 61, 65-93.

O'Barr, W., \& Conley, J. (1992). Fortune and foley: The wealth and power of institutional investing. Business One, Irwin Publishing, Homewood, IL.

Orlitzky, M., \& Benjamin, J. (2001). Corporate social responsibility and firm risk: A metaanalytic review. Business and Society, 40, 369-396.

Orlinzky, M., Schmidt, F., \& Rynes, S. (2003). Corporate social and financial performance: A meta-analysis. Organizational Studies, 24, 403-411.

Porter, M.E., \& Van der Linde, C. (1995). Toward a new conception of the environmentcompetitiveness relationship. Journal of Economic Perspectives, 9, 97-118.

Potter, G. (1992). Accounting earnings announcements, institutional investor concentration, and common stock returns. Journal of Accounting Research, 30, 146-55.

Prior, D., Surroca, J., \& Tribo, J. (2008). Are socially responsible managers really ethical? Exploring the relationship between earnings management and corporate social responsibility. Corporate Governance: An International Review, 16, 160-177.

Ramalingegowda, S., \& Yu, Y. (2012). Institutional ownership and conservatism. Journal of Accounting and Economics, 53, 98-114.

Roman, R., Hayibor, S., \& Agle, B. (1999). The relationship between social performance and financial performance. Business and Society, Vol. 38, pp. 109-125.

Rupert, D. (2004). Statistics and finance: An introduction. Springer-Verlag, New York, NY.

Saiia, D. H., Carroll, A. B., \& Buchholtz, A. K. (2003). Philanthropy as strategy: When corporate charity “Begins at Home.” Business \& Society, 42, 169-201.

Scholtens, B. (2008). A note on the interaction between corporate social responsibility and financial performance. Ecological Economics, 68, 46-55.

Sen, S., \& Bhattacharya, C.B. (2001). Does doing good always lead to doing better? Consumer reactions to corporate social responsibility. Journal of Marketing Research, Vol. 38, pp. $225-243$.

Sharfman, M.P., \& Fernando, C. S. (2008). Environmental risk management and the cost of capital. Strategic Management Journal, 29, 569-592. 
Sias, R. W. (1996). Volatility and the institutional investor. Financial Analysts Journal, 52, 1320.

Sievanent, R., Rita, H., \& Scholtens, B. (2012). The drivers of responsible investment: The case of European pension funds. Journal of Business Ethics, 117, 137-15.

Spicer, B.H. (1978). Investors, corporate social performance, and information disclosure: An empirical study. The Accounting Review, 53, 94-111.

Stage, F., Carter, H., \& Nora, A. (2004). Path analysis: An introduction and analysis of a decade of research. Journal of Education Research, 98, 5-13.

Turban, D. B., \& Greening, D. W. (1996). Corporate social performance and organizational attractiveness to prospective employees. Academy of Management Journal, 40, 658-672.

Ullmann, A. A. (1985). Data in search of a theory: A critical examination of the relationships among social performance, social disclosure, and economic performance of U.S. firms. Academy of Management Review, 10, 540-557.

Waddock, S., \& Graves, S. (1997). The corporate social performance-financial performance link. Strategic Management Journal, 18, 303-319.

Wang, H., Choi, J., \& Li, J. (2008). Too little or too much? Untangling the relationship between corporate philanthropy and firm financial performance. Organization Science, 19, 143159.

Wright, S. (1921). Correlation and causation. Journal of Agricultural Research, 20, 557-585.

Wright, S. (1923). The theory of path coefficients: A reply to Niles's criticism. Genetics, 8, 239255. 


\section{Appendix A. Definitions of Institutional Ownership, CSR Measures, and Stock Return Volatility}

\begin{tabular}{|c|c|}
\hline Variable Name & Variable Definition \\
\hline PCTINSTI & $\begin{array}{l}\text { Yearend shareholdings of all institutional investors relative to total shares } \\
\text { outstanding }\end{array}$ \\
\hline BNK & Yearend shareholdings of banks and trusts relative to total shares outstanding \\
\hline INS & Yearend shareholdings of insurance companies relative to total shares outstanding \\
\hline INVIIA & $\begin{array}{l}\text { Yearend shareholdings of investment banks and independent investment advisers } \\
\text { relative to total shares outstanding }\end{array}$ \\
\hline MISC & $\begin{array}{l}\text { Yearend shareholdings of pension funds, foundations, endowments, and } \\
\text { miscellaneous institutions relative to total shares outstanding }\end{array}$ \\
\hline CSRIDX $(\mathrm{t}-1)$ & $\begin{array}{l}\text { CSR index for year } \mathrm{t}-1 \text {, measured as total strengths minus total concerns, based on } \\
\text { five social rating categories in KLD data: community, diversity, employee relations, } \\
\text { environment, and product, standardized in each industry for each year to range from } \\
0 \text { to } 1 \text {, where year } t \text { is the year that institutional ownership is measured }\end{array}$ \\
\hline CSRIDX_C(t-1) & $\begin{array}{l}\text { Centered CSR index for year } \mathrm{t}-1 \text {, where year } \mathrm{t} \text { is the year that institutional ownership } \\
\text { is measured }\end{array}$ \\
\hline CSRIDX_C2(t-1) & $\begin{array}{l}\text { Centered CSR index squared for year } t-1 \text {, where year } t \text { is the year that institutional } \\
\text { ownership is measured }\end{array}$ \\
\hline $\operatorname{DEVRET}(\mathrm{t}+1)$ & $\begin{array}{l}\text { Natural logarithm of the standard deviation of daily stock returns for year } \mathrm{t}+1 \text {, where } \\
\text { year } \mathrm{t} \text { is the year that institutional ownership is measured }\end{array}$ \\
\hline TOBINQ & $\begin{array}{l}\text { Market value of equity plus book values of long-term and short-term debts divided } \\
\text { by total assets. }\end{array}$ \\
\hline
\end{tabular}




\section{Appendix B. Definitions of Control Variables for institutional ownership and return volatility}

\begin{tabular}{|c|c|c|}
\hline Variable Name & Variable Definition & Reference \\
\hline MRET & $\begin{array}{l}\text { Market-adjusted buy-and-hold returns measured over a year's time; } \\
[\mathrm{P}(\mathrm{t})-\mathrm{P}(\mathrm{t}-1)+\mathrm{DIV}(\mathrm{t})) / \mathrm{P}(\mathrm{t}-1)] \text { minus [S\&P500(t) - S\&P500(t-1)+ } \\
\mathrm{S} \& \mathrm{P} 500 \mathrm{DIV}) / \mathrm{S} \& \mathrm{P} 500(\mathrm{t}-1)] \text {, where } \mathrm{P} \text { is price of firm's stock, DIV is } \\
\text { total cash dividends, and S\&P500 is the S\&P500 Index }\end{array}$ & Bushee and Noe (2000) \\
\hline TVOL & $\begin{array}{l}\text { Average monthly trading volume relative to total shares outstanding } \\
\text { measured over a year's time }\end{array}$ & Bushee and Noe (2000) \\
\hline BETA & $\begin{array}{l}\text { Market-model beta estimated from the slope of market model: } R_{i}=a+ \\
B E T A^{*} R_{M}+\varepsilon_{l} \text {, where } R_{i} \text { is firm's daily stock returns, } R_{M} \text { is the S\&P500 } \\
\text { daily returns, both measured over a year, and } \varepsilon_{i} \text { is the residual error } \\
\text { from market model }\end{array}$ & Bushee and Noe (2000) \\
\hline IRISK & $\begin{array}{l}\text { Natural logarithm of the standard deviation of market-model residuals }\left(\varepsilon_{i}\right) \\
\text { calculated from daily stock returns over a year }\end{array}$ & Bushee and Noe (2000) \\
\hline MKTVAL & $\begin{array}{l}\text { Natural logarithm of market value of common equity; natural logarithm } \\
\text { of (PRCC_C x CSHO) where PRCC_C is the stock price at yearend } \\
\text { and CSHO is common shares outstanding (in million shares) at } \\
\text { yearend. }\end{array}$ & Bushee and Noe (2000) \\
\hline DEBTR & $\begin{array}{l}\text { Ratio of debt to total assets; IB/(PRCC_C x CSHO), where IB is the } \\
\text { income before extraordinary item, PRCC_C is the stock price at yearend, } \\
\text { and CSHO is common shares outstanding (in million shares) at yearend }\end{array}$ & Bushee and Noe (2000) \\
\hline EP & $\begin{array}{l}\text { Ratio of income before extraordinary item to market value of } \\
\text { common equity }\end{array}$ & Bushee and Noe (2000) \\
\hline BP & $\begin{array}{l}\text { Ratio of book value of common equity to market value of common } \\
\text { equity; CEQ/(PRCC_C x CSHO), where CEQ is the book value of } \\
\text { common equity, PRCC_C is the stock price at yearend, and CSHO is } \\
\text { common shares outstanding (in million shares) at yearend }\end{array}$ & Bushee and Noe (2000) \\
\hline DP & $\begin{array}{l}\text { Ratio of dividends to market value of equity; DVT/(PRCC_C } \mathrm{x} \\
\mathrm{CSHO} \text {, where DVT is the total cash dividends, PRCC_C is the stock } \\
\text { price at yearend, and CSHO is common shares outstanding (in million } \\
\text { shares) at yearend }\end{array}$ & Bushee and Noe (2000) \\
\hline SALEGRW & $\begin{array}{l}\text { Percentage change in annual sales from the previous year; }[\mathrm{REVT}(\mathrm{t})- \\
\mathrm{REVT}(\mathrm{t}-1)] / \operatorname{REVT}(\mathrm{t}) \text {, where REVT is the annual total revenue (in } \\
\text { million dollars) }\end{array}$ & Bushee and Noe (2000) \\
\hline SP500 & $\begin{array}{l}\text { Indicator variable that equals one if a firm is listed in the S\&P500 } \\
\text { index and zero otherwise }\end{array}$ & Bushee and Noe (2000) \\
\hline SPRATING & $\mathrm{S} \& \mathrm{P}$ stock rating $(\mathrm{A}+=9, \mathrm{~A}=8, \mathrm{~B}+=7$, etc. $)$ & Bushee and Noe (2000) \\
\hline SHROUT & $\begin{array}{l}\text { Natural logarithm of common shares outstanding (CSHO), where } \\
\text { CSHO is common shares outstanding (in million shares) at yearend }\end{array}$ & Bushee and Noe (2000) \\
\hline FIRMAGE & Number of years the firm has been listed in the CRSP database & Bushee (2001) \\
\hline CEPS & $\begin{array}{l}\text { Changes in annual earnings per share deflated by prior stock price; } \\
\text { [EPSPI }(t)-\text { EPSPI }(t-1)] / P R C C \_C(t-1) \text {, where EPSPI is the earnings } \\
\text { per share and PRCC_C is the stock price at yearend }\end{array}$ & Bushee (2001) \\
\hline RNDR & $\begin{array}{l}\text { Ratio of research and development expense to sales; XRD/REVT, } \\
\text { where XRD is R\&D expense and REVT is the total revenue }\end{array}$ & Bushee (2001) \\
\hline
\end{tabular}




\section{Appendix C. Definitions of Control Variables for CSR}

\begin{tabular}{|c|c|c|}
\hline Variable Name & Variable Definition & Reference \\
\hline ROA & Income before extraordinary items (IB) divided by total assets (AT) & $\begin{array}{l}\text { Waddock and Graves } \\
\text { (1997) }\end{array}$ \\
\hline DEVRET & $\begin{array}{l}\text { Natural logarithm of the standard deviation of daily stock returns for } \\
\text { year }\end{array}$ & Campbell (2007) \\
\hline MKTBK & $\begin{array}{l}\text { Market value of common equity (PRCC_C x CSHO) divided by the } \\
\text { book value of equity (CEQ) }\end{array}$ & El Ghoul et al. (2011) \\
\hline RNDR & $\begin{array}{l}\text { Ratio of research and development expense to sales; XRD/REVT, } \\
\text { where XRD is R\&D expense and REVT is the total revenue }\end{array}$ & $\begin{array}{l}\text { McWilliams and Siegel } \\
(2001)\end{array}$ \\
\hline LOGASSET & Natural log of total asset $(\ln (\mathrm{AT}))$ & $\begin{array}{l}\text { Waddock and Graves } \\
\text { (1997) }\end{array}$ \\
\hline SEGMENTS & The number of business segments for each firm (BUSSEG) & $\begin{array}{l}\text { McWilliams and Siegel } \\
(2001)\end{array}$ \\
\hline LOGANALYST & $\begin{array}{l}\text { Natural logarithm of number of analyst followings (ln(NUMEST)) } \\
\text { Data source: I/B/E/S }\end{array}$ & $\begin{array}{l}\text { Ioannou and Serafeim } \\
(2010)\end{array}$ \\
\hline HHI & $\begin{array}{l}\text { Herfindahl-Hirschman Index calculated from the sum of squared of } \\
\text { market share bases on net sales for each firm relative to the total } \\
\text { industry net sales within the same industry based on the Fama-French } \\
48 \text { industries }\end{array}$ & Campbell (2007) \\
\hline DEBTR & $\begin{array}{l}\text { Ratio of debt to total assets; } \mathrm{IB} /(\mathrm{PRCC} C \mathrm{C} \times \mathrm{CSHO}) \text {, where IB is the } \\
\text { income before extraordinary item, PRCC_C is the stock price at yearend, } \\
\text { and CSHO is common shares outstanding (in million shares) at yearend }\end{array}$ & Prior et al. (2008) \\
\hline CASHFLOW & $\begin{array}{l}\text { Cash flows from operating activities (OANCF) divided by total assets } \\
\text { (AT) }\end{array}$ & Prior et al. (2008) \\
\hline MEDIANCSR & $\begin{array}{l}\text { The industry median of CSRIDX based on the Fama-French } 48 \\
\text { industry }\end{array}$ & El Ghoul et al. (2011) \\
\hline
\end{tabular}


Figure 1

Benefit, Cost, and Net Benefit of CSR

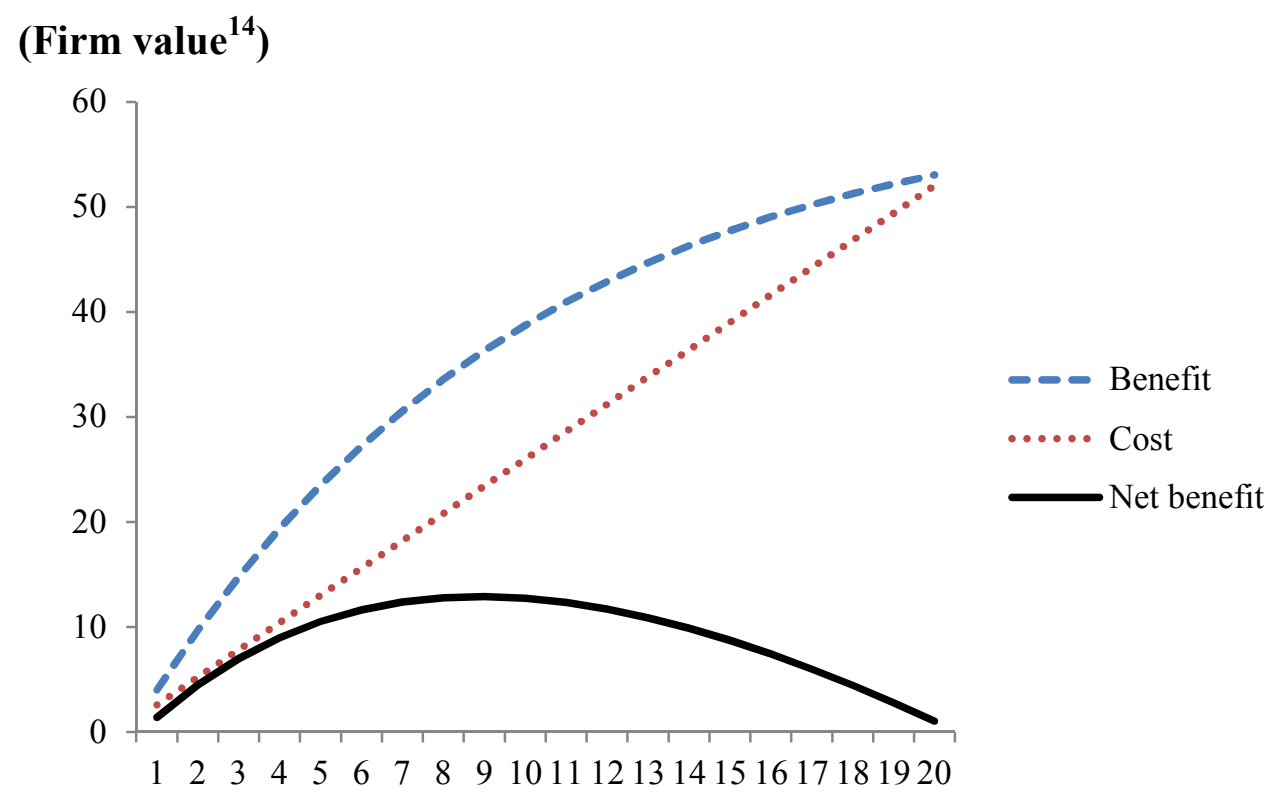

(CSR)

Figure 2

The Relationship between CSR and Stock Return Volatility

(CSR)

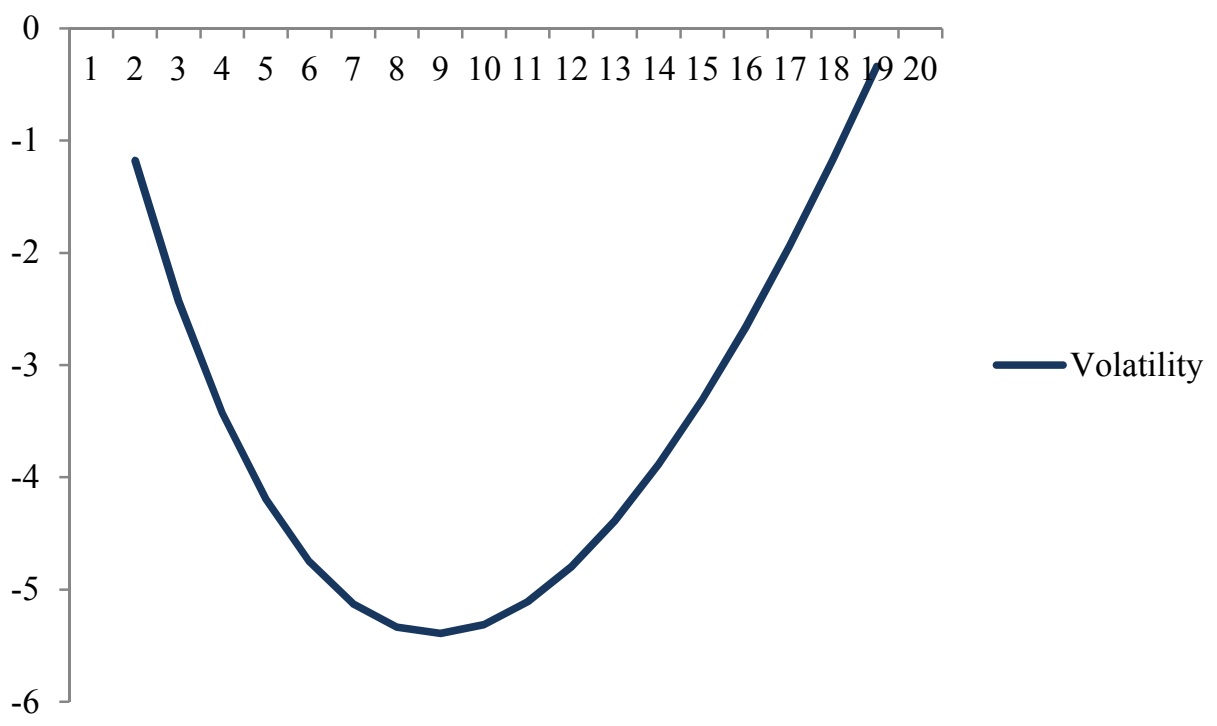

(DEVRET)

\footnotetext{
${ }^{14}$ Following the finance literature, we define firm value as the present value of expected future cash flows. Thus one dollar spent on CSR activities today will decrease firm value by one dollar.
} 
Figure 3

Path Diagram

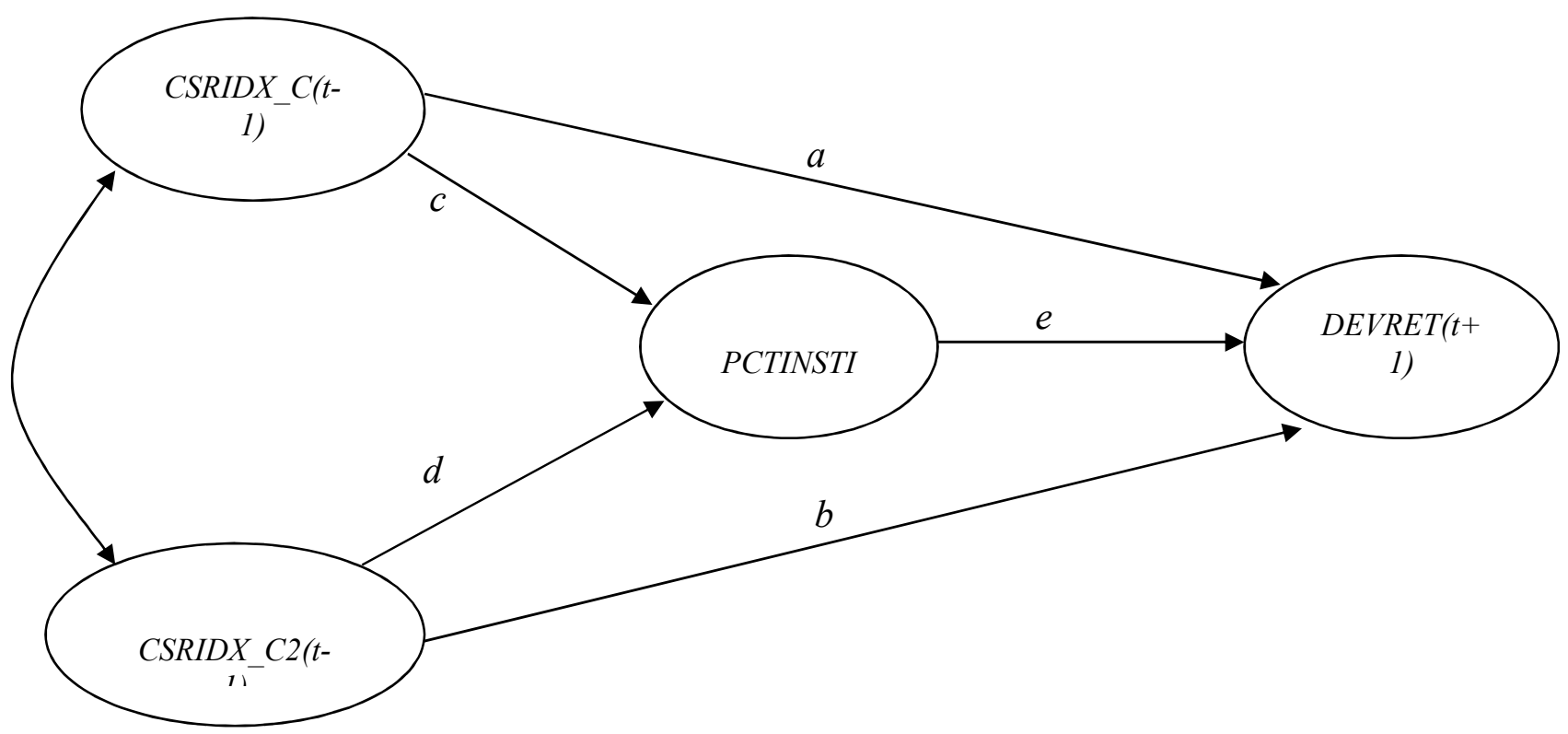

$a$ : direct effect of centered CSR index (CSRIDX_C(t-1)) on stock return volatility $(\operatorname{DEVRET}(\mathrm{t}+1))$

$b$ : direct effect of centered CSR index squared (CSRIDX_C2(t-1)) on stock return volatility $(\operatorname{DEVRET}(\mathrm{t}+1))$

$c \times e$ : indirect effect of CSRIDX_C(t-1) on stock return volatility through institutional ownership (PCTINSTI)

$d \times e$ : indirect effect of CSRIDX_C2(t-1) on stock return volatility through institutional ownership (PCTINSTI) 
Table 1. Sample Distribution

\begin{tabular}{|c|c|c|c|c|c|}
\hline Industry & Fama-French Industry Number & Observations & Percent $(\%)$ & PCTINSTI & CSRIDX(t-1) \\
\hline Banks & 34 & 1023 & 7.85 & 0.75 & 0.30 \\
\hline Retail & 44 & 994 & 7.63 & 0.58 & 0.32 \\
\hline Bus. Svc & 31 & 821 & 6.3 & 0.59 & 0.51 \\
\hline Chips & 42 & 795 & 6.1 & 0.72 & 0.42 \\
\hline Util & 36 & 752 & 5.77 & 0.75 & 0.32 \\
\hline Drugs & 47 & 642 & 4.93 & 0.69 & 0.40 \\
\hline Insurance & 13 & 605 & 4.64 & 0.69 & 0.38 \\
\hline Machine & 30 & 582 & 4.47 & 0.76 & 0.55 \\
\hline Trading Fin & 21 & 571 & 4.38 & 0.73 & 0.39 \\
\hline Energy & 45 & 566 & 4.34 & 0.72 & 0.43 \\
\hline Chemicals & 14 & 415 & 3.18 & 0.72 & 0.53 \\
\hline Computer & 35 & 397 & 3.05 & 0.72 & 0.28 \\
\hline Food & 41 & 348 & 2.67 & 0.78 & 0.44 \\
\hline Med. Eq. & 12 & 320 & 2.46 & 0.76 & 0.37 \\
\hline Transport & 40 & 309 & 2.37 & 0.75 & 0.40 \\
\hline Telecom & 37 & 283 & 2.17 & 0.79 & 0.29 \\
\hline Wholesale & 32 & 279 & 2.14 & 0.63 & 0.51 \\
\hline Paper & 17 & 272 & 2.09 & 0.73 & 0.40 \\
\hline Household & 38 & 266 & 2.04 & 0.74 & 0.43 \\
\hline Build. Mat. & 2 & 261 & 2 & 0.58 & 0.43 \\
\hline Lab. Eq. & 9 & 251 & 1.93 & 0.64 & 0.42 \\
\hline Books & 23 & 204 & 1.57 & 0.69 & 0.44 \\
\hline Clothes & 43 & 203 & 1.56 & 0.72 & 0.42 \\
\hline Autos & 10 & 183 & 1.4 & 0.69 & 0.44 \\
\hline Elec. Eq. & 19 & 177 & 1.36 & 0.72 & 0.49 \\
\hline Meals & 22 & 176 & 1.35 & 0.71 & 0.53 \\
\hline Steel & 18 & 159 & 1.22 & 0.78 & 0.49 \\
\hline Construct & 8 & 142 & 1.09 & 0.71 & 0.53 \\
\hline Aero & 24 & 139 & 1.07 & 0.73 & 0.42 \\
\hline Person Svc. & 7 & 134 & 1.03 & 0.62 & 0.55 \\
\hline Health & 33 & 117 & 0.9 & 0.75 & 0.49 \\
\hline Toys & 11 & 104 & 0.8 & 0.83 & 0.39 \\
\hline Fun/Enter & 39 & 75 & 0.58 & 0.74 & 0.46 \\
\hline Boxes & 6 & 71 & 0.54 & 0.79 & 0.56 \\
\hline Beer & 15 & 57 & 0.44 & 0.79 & 0.60 \\
\hline Rubber & 48 & 47 & 0.36 & 0.67 & 0.42 \\
\hline Gold & 28 & 46 & 0.35 & 0.70 & 0.48 \\
\hline Others & 4 & 42 & 0.32 & 0.72 & 0.47 \\
\hline Mines & 26 & 28 & 0.21 & 0.76 & 0.57 \\
\hline Ships & 29 & 28 & 0.21 & 0.85 & 0.65 \\
\hline Textiles & 3 & 23 & 0.18 & 0.53 & 0.56 \\
\hline Smoke & 25 & 23 & 0.18 & 0.75 & 0.52 \\
\hline Soda & 16 & 22 & 0.17 & 0.74 & 0.61 \\
\hline Agricult & 27 & 21 & 0.16 & 0.64 & 0.37 \\
\hline Guns & 1 & 20 & 0.15 & 0.75 & 0.35 \\
\hline Coal & 5 & 19 & 0.15 & 0.65 & 0.66 \\
\hline Real Est. & 46 & 16 & 0.12 & 0.82 & 0.51 \\
\hline Fabric. Prod & 20 & 5 & 0.04 & 0.68 & 0.50 \\
\hline Total & & 13033 & 100 & 0.70 & 0.41 \\
\hline
\end{tabular}


Table 2. Summary Statistics

Panel A: Descriptive Statistics

\begin{tabular}{lcccccccc}
\hline Variable & Obs & Mean & Median & $\begin{array}{c}25 \text { th } \\
\text { Pctile }\end{array}$ & $\begin{array}{c}75 \text { th } \\
\text { Pctile }\end{array}$ & Std. Dev. & Min & Max \\
\hline CSRIDX(t-1) & 13033 & 0.4126 & 0.3750 & 0.2105 & 0.5714 & 0.2595 & 0 & 1 \\
PCTINSTI & 13033 & 0.7049 & 0.7328 & 0.5962 & 0.8443 & 0.1784 & 0.1953 & 0.9899 \\
BNK & 13033 & 0.1255 & 0.1218 & 0.0849 & 0.1609 & 0.0553 & 0.0214 & 0.6382 \\
INS & 13033 & 0.0380 & 0.0306 & 0.0190 & 0.0482 & 0.0282 & 0.0038 & 0.6379 \\
INVIIA & 13033 & 0.4822 & 0.4908 & 0.3704 & 0.5982 & 0.1567 & 0.0722 & 0.9080 \\
MISC & 13033 & 0.0535 & 0.0483 & 0.0331 & 0.0662 & 0.0309 & 0.0068 & 0.6715 \\
DEVRET(t+1) & 13033 & -3.7925 & -3.8083 & -4.1185 & -3.4814 & 0.4568 & -7.7598 & -0.8596 \\
MRET & 13033 & 0.0073 & -0.0531 & -0.2827 & 0.2134 & 0.4495 & -0.7962 & 1.7631 \\
TVOL & 13033 & 0.2632 & 0.1841 & 0.0949 & 0.3613 & 0.9751 & 0.0205 & 0.9355 \\
BETA & 13033 & 1.1447 & 1.0939 & 0.8100 & 1.4279 & 0.4649 & 0.1439 & 2.8168 \\
IRISK & 13033 & 0.0202 & 0.0179 & 0.0129 & 0.0248 & 0.0101 & 0.0069 & 0.0692 \\
MKTVAL & 13033 & 7.9135 & 7.8569 & 6.7053 & 9.0138 & 1.5798 & 4.6331 & 12.9782 \\
DEBTR & 13033 & 0.2048 & 0.1789 & 0.0503 & 0.3070 & 0.1794 & 0 & 0.8123 \\
EP & 13033 & 0.0308 & 0.0512 & 0.0280 & 0.0705 & 0.1080 & -0.3824 & 0.4947 \\
BP & 13033 & 0.5140 & 0.4498 & 0.2721 & 0.6827 & 0.3498 & -0.1692 & 2.2588 \\
DP & 13033 & 0.0171 & 0.0119 & 0 & 0.0261 & 0.0204 & 0 & 0.1267 \\
SALEGRW & 13033 & 0.0868 & 0.0705 & -0.0086 & 0.1568 & 0.1996 & -0.4499 & 0.9698 \\
SP500 & 13033 & 0.4889 & 0 & 0 & 1 & 0.4999 & 0 & 1 \\
SPRATING & 13033 & 5.2233 & 5 & 4 & 6 & 1.8145 & 1 & 9 \\
SHROUT & 13033 & 4.6320 & 4.4960 & 3.7280 & 5.4266 & 1.2441 & 2.0874 & 8.3726 \\
FIRMAGE & 13033 & 28.0146 & 23.0219 & 13.1726 & 37.8192 & 19.5996 & 3.4723 & 83.8615 \\
CEPS & 13033 & 0.0092 & 0.0047 & -0.0143 & 0.0203 & 0.1130 & -0.4019 & 0.8593 \\
RNDR & 13033 & 0.0500 & 0 & 0 & 0.0321 & 0.1533 & 0 & 0.2793 \\
\hline
\end{tabular}


Panel B: Mean Institutional Ownership by CSRIDX(t-1) Quintiles

\begin{tabular}{|c|c|c|c|c|c|c|c|}
\hline & PCTINSTI & $\mathrm{BNK}$ & INS & INVIIA & MISC & TOBINQ & $\operatorname{DEVRET}(\mathrm{t}+1)$ \\
\hline Lowest quintile & 0.7053 & 0.1140 & 0.0358 & 0.5017 & 0.0529 & 1.3539 & -3.7181 \\
\hline $2^{\text {nd }}$ quintile & 0.7161 & 0.1159 & 0.0345 & 0.5059 & 0.0532 & 1.6022 & -3.7561 \\
\hline $3^{\text {rd }}$ quintile & 0.7148 & 0.1282 & 0.0390 & 0.4936 & 0.0544 & 1.7551 & -3.7776 \\
\hline $4^{\text {th }}$ quintile & 0.6951 & 0.1401 & 0.0409 & 0.4640 & 0.0560 & 1.4825 & -3.7637 \\
\hline Highest quintile & 0.6886 & 0.1326 & 0.0435 & 0.4456 & 0.0504 & 1.4736 & -3.7616 \\
\hline
\end{tabular}

See Appendices A and B for variable definitions. 
Table 3. Pearson Correlations

\begin{tabular}{|c|c|c|c|c|c|c|c|c|c|c|c|c|c|c|c|c|}
\hline No & Variables & 1 & 2 & 3 & 4 & 5 & 6 & 7 & 8 & 9 & 10 & 11 & 12 & 13 & 14 & 15 \\
\hline 1 & MRET & 1 & & & & & & & & & & & & & & \\
\hline 2 & TVOL & $0.0489 *$ & 1 & & & & & & & & & & & & & \\
\hline 3 & BETA & $0.1275^{*}$ & $0.2753^{*}$ & 1 & & & & & & & & & & & & \\
\hline 4 & IRISK & $0.1650 *$ & $0.2939 *$ & $0.4231 *$ & 1 & & & & & & & & & & & \\
\hline 5 & MKTVAL & $0.0280 *$ & -0.0103 & $-0.2439 *$ & $-0.4281 *$ & 1 & & & & & & & & & & \\
\hline 6 & DEBTR & 0.0158 & $0.0517^{*}$ & $-0.0427 *$ & $0.0336^{*}$ & 0.016 & 1 & & & & & & & & & \\
\hline 7 & EP & $-0.0686^{*}$ & $-0.0794 *$ & $-0.1193 *$ & $-0.3158^{*}$ & $0.1639 *$ & $-0.0977^{*}$ & 1 & & & & & & & & \\
\hline 8 & $\mathrm{BP}$ & $-0.1359 *$ & $-0.0293 *$ & $0.1450 *$ & $0.2081 *$ & $-0.2780 *$ & $-0.1208^{*}$ & $0.1473 *$ & 1 & & & & & & & \\
\hline 9 & DP & $-0.0905^{*}$ & $-0.1657^{*}$ & $-0.0845^{*}$ & $-0.0339 *$ & 0.0034 & $0.2088^{*}$ & $0.0378^{*}$ & $0.2126^{*}$ & 1 & & & & & & \\
\hline 10 & SALEGRW & -0.0004 & $-0.0467 *$ & 0.0103 & 0.0179 & -0.0002 & -0.011 & -0.0018 & -0.0192 & -0.0117 & 1 & & & & & \\
\hline 11 & SP500 & $-0.0234 *$ & 0.0185 & $-0.2478^{*}$ & $-0.2326^{*}$ & $0.7026^{*}$ & $0.0290 *$ & $0.0611^{*}$ & $-0.1626^{*}$ & 0.022 & -0.0151 & 1 & & & & \\
\hline 12 & SPRATING & -0.0078 & $-0.2883 *$ & $-0.2888 *$ & $-0.3724 *$ & $0.4232 *$ & $-0.0686^{*}$ & $0.1331^{*}$ & $-0.1765^{*}$ & $0.0447 *$ & $0.0260 *$ & $0.3311^{*}$ & 1 & & & \\
\hline 13 & SHROUT & -0.022 & $0.0949 *$ & $-0.0961 *$ & $-0.1773 *$ & $0.8582 *$ & $0.0828^{*}$ & 0.0169 & $-0.1525^{*}$ & $0.0410^{*}$ & -0.0002 & $0.6441^{*}$ & $0.2433^{*}$ & 1 & & \\
\hline 14 & FIRMAGE & $-0.0261 *$ & $-0.3142 *$ & $-0.2385^{*}$ & $-0.2672 *$ & $0.3718 *$ & $0.0574 *$ & $0.0641 *$ & $-0.0522 *$ & $0.1168^{*}$ & -0.0178 & $0.4203 *$ & $0.3230^{*}$ & $0.3009^{*}$ & 1 & \\
\hline 15 & CEPS & $0.3422 *$ & $0.0332 *$ & $0.0995^{*}$ & $0.1638^{*}$ & $-0.0314 *$ & $0.0506^{*}$ & $0.1815^{*}$ & $-0.0581 *$ & -0.0224 & 0.0038 & -0.0191 & $-0.0360 *$ & 0.0019 & $-0.0269 *$ & 1 \\
\hline 16 & RNDR & -0.0047 & 0.014 & -0.0019 & $0.0444 *$ & -0.0145 & $-0.0240 *$ & $-0.0314 *$ & -0.0097 & -0.0068 & 0.0015 & -0.0124 & -0.0163 & 0.0014 & -0.0143 & 0.0026 \\
\hline
\end{tabular}

See Appendix B for variable definitions. * indicates two-tailed significance at $1 \%$ level. 
Table 4. Impact of CSR on Institutional Ownership

\begin{tabular}{|c|c|c|}
\hline & PCTINSTI & PCTINSTI \\
\hline $\operatorname{CSRIDX}(\mathrm{t}-1)$ & $\begin{array}{c}-0.0089 \\
(0.79)\end{array}$ & \\
\hline CSRIDX_C(t-1) & & $\begin{array}{c}0.0211 \\
(1.58)\end{array}$ \\
\hline CSRIDX_C2(t-1) & & $\begin{array}{c}-0.1099 \\
(3.78) * * *\end{array}$ \\
\hline MRET & $\begin{array}{l}-0.0107 \\
(2.51)^{* *}\end{array}$ & $\begin{array}{l}-0.0104 \\
(2.44)^{* *}\end{array}$ \\
\hline TVOL & $\begin{array}{c}0.0476 \\
(10.47)^{* * *}\end{array}$ & $\begin{array}{c}0.0469 \\
(10.34)^{* * *}\end{array}$ \\
\hline BETA & $\begin{array}{c}0.0044 \\
(0.69)\end{array}$ & $\begin{array}{c}0.0040 \\
(0.62)\end{array}$ \\
\hline IRISK & $\begin{array}{c}-2.5866 \\
(6.55)^{* * *}\end{array}$ & $\begin{array}{c}-2.5838 \\
(6.56)^{* * *}\end{array}$ \\
\hline MKRTVAL & $\begin{array}{c}0.0345 \\
(6.46)^{* * *}\end{array}$ & $\begin{array}{c}0.0342 \\
(6.43)^{* * *}\end{array}$ \\
\hline DEBTR & $\begin{array}{c}0.1501 \\
(7.93)^{* * *}\end{array}$ & $\begin{array}{c}0.1502 \\
(7.94)^{* * *}\end{array}$ \\
\hline EP & $\begin{array}{c}0.0056 \\
(0.25)\end{array}$ & $\begin{array}{c}0.0063 \\
(0.29)\end{array}$ \\
\hline BP & $\begin{array}{c}0.0616 \\
(6.65)^{* * *}\end{array}$ & $\begin{array}{c}0.0617 \\
(6.69)^{* * *}\end{array}$ \\
\hline DP & $\begin{array}{c}-1.1698 \\
(7.93)^{* * *}\end{array}$ & $\begin{array}{c}-1.1790 \\
(8.01)^{* * *}\end{array}$ \\
\hline SALEGRW & $\begin{array}{c}-0.0124 \\
(1.48)\end{array}$ & $\begin{array}{c}-0.0127 \\
(1.52)\end{array}$ \\
\hline SP500 & $\begin{array}{c}0.0448 \\
(4.74)^{* * *}\end{array}$ & $\begin{array}{c}0.0441 \\
(4.71)^{* * *}\end{array}$ \\
\hline SPRATING & $\begin{array}{c}-0.0004 \\
(0.21)\end{array}$ & $\begin{array}{c}-0.0004 \\
(0.18)\end{array}$ \\
\hline SHROUT & $\begin{array}{c}-0.0510 \\
(8.60)^{* * *}\end{array}$ & $\begin{array}{c}-0.0500 \\
(8.47)^{* * *}\end{array}$ \\
\hline FIRMAGE & $\begin{array}{c}0.0003 \\
(1.61)\end{array}$ & $\begin{array}{l}0.0003 \\
(1.67)^{*}\end{array}$ \\
\hline CEPS & $\begin{array}{l}-0.0361 \\
(2.47)^{* *}\end{array}$ & $\begin{array}{l}-0.0359 \\
(2.46)^{* *}\end{array}$ \\
\hline RNDR & $\begin{array}{c}-0.0700 \\
(2.85) * * *\end{array}$ & $\begin{array}{c}-0.0684 \\
(2.79)^{* * *}\end{array}$ \\
\hline Constant & $\begin{array}{c}0.3538 \\
(7.90)^{* * *}\end{array}$ & $\begin{array}{c}0.3567 \\
(7.81)^{* * *}\end{array}$ \\
\hline Industry Dummies & Yes & Yes \\
\hline Year Dummies & Yes & Yes \\
\hline Observations & 13033 & 13033 \\
\hline R-squared & 0.3109 & 0.3129 \\
\hline
\end{tabular}

See Appendices A and B for variable definitions. ***, **, and * indicate two-tailed significance at $1 \%, 5 \%$, and $10 \%$ level, respectively. 
Table 5. Impact of CSR on Holdings by Various Institution Types

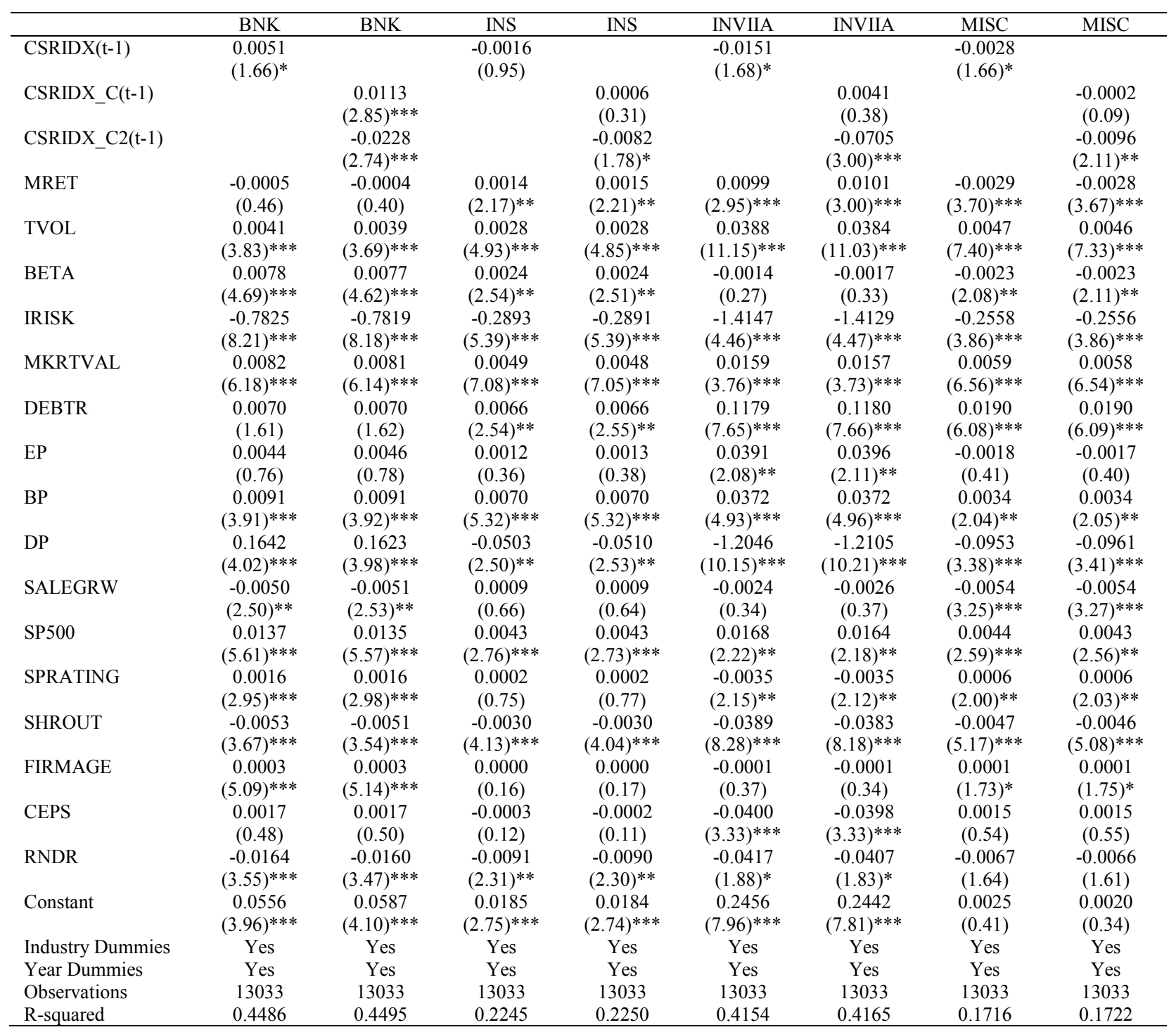

See Appendices A and B for variable definitions. ***, **, and * indicate two-tailed significance at $1 \%, 5 \%$, and $10 \%$ level, respectively. 
Table 6. Direct and Indirect Impact of CSR on Stock Return Volatility

Panel A: Regression of Stock Return Volatility on Institutional Ownership and CSR

\begin{tabular}{|c|c|c|}
\hline \multirow{3}{*}{ PCTINSTI } & DEVRET $(t+1)$ & DEVRET $(\mathrm{t}+1)$ \\
\hline & -0.1019 & \\
\hline & $(7.11)^{* * *}$ & \\
\hline BNK & & $\begin{array}{c}-0.2550 \\
(4.90)^{* * *}\end{array}$ \\
\hline INS & & -0.0188 \\
\hline INVIIA & & $\begin{array}{l}-0.0455 \\
(2.54) * *\end{array}$ \\
\hline MISC & & -0.5448 \\
\hline CSRIDX_C(t-1) & $\begin{array}{l}0.0185 \\
(1.52)\end{array}$ & $\begin{array}{c}0.0192 \\
(1.57)\end{array}$ \\
\hline CSRIDX_C2(t-1) & $\begin{array}{l}0.0013 \\
(0.05)\end{array}$ & $\begin{array}{c}-0.0018 \\
(0.06)\end{array}$ \\
\hline MRET & $\begin{array}{c}0.0319 \\
(40 * * *\end{array}$ & $\begin{array}{c}0.0316 \\
(466 * * * *\end{array}$ \\
\hline TVOL & $\begin{array}{c}0.0675 \\
(22.87)^{* * *}\end{array}$ & $\begin{array}{c}0.0678 \\
(22.86) * * *\end{array}$ \\
\hline MKTVAL & -0.1446 & -0.1414 \\
\hline DEBTR & $\begin{array}{c}(37.05)^{* * * *} \\
0.0222 \\
(1.56)\end{array}$ & $\begin{array}{c}(35.82)^{* * *} \\
0.0244 \\
(1.71)^{*}\end{array}$ \\
\hline EP & -0.5126 & -0.5087 \\
\hline BP & $\begin{array}{l}0.0250 \\
(3.12)^{* * * *}\end{array}$ & $\begin{array}{c}0.0246 \\
(3.08) * * *\end{array}$ \\
\hline DP & $\begin{array}{c}-1.6810 \\
(12.69)^{* * *}\end{array}$ & $\begin{array}{c}-1.6228 \\
(12.16)^{* * *}\end{array}$ \\
\hline SALEGRW & 0.1151 & $\begin{array}{l}0.1117 \\
(9.45)^{* * * *}\end{array}$ \\
\hline SP500 & $\begin{array}{c}0.0287 \\
(4.08)^{* * * *}\end{array}$ & $\begin{array}{c}0.0308 \\
(4.37)^{* * *}\end{array}$ \\
\hline SPRATING & $\begin{array}{c}-0.0282 \\
(18.59)^{* * *}\end{array}$ & $\begin{array}{c}-0.0276 \\
(18.11)^{* * *}\end{array}$ \\
\hline SHROUT & $\begin{array}{l}0.0902 \\
(2087 * * *\end{array}$ & $\begin{array}{c}0.0893 \\
(2061)^{* * *}\end{array}$ \\
\hline FIRMAGE & $\begin{array}{c}-0.0006 \\
(4.11)^{* * *}\end{array}$ & $\begin{array}{c}-0.0005 \\
(3.59)^{* * * *}\end{array}$ \\
\hline CEPS & $\begin{array}{l}0.1176 \\
(5.36 * * *\end{array}$ & $\begin{array}{l}0.1194 \\
(5.66 * * *\end{array}$ \\
\hline RNDR & $\begin{array}{c}0.0927 \\
\left(4.633^{* * * *}\right.\end{array}$ & $\begin{array}{l}0.0898 \\
(4.49)^{* * * *}\end{array}$ \\
\hline Constant & $\begin{array}{c}-3.5069 \\
(117.41)^{* * *}\end{array}$ & $\begin{array}{c}-3.5207 \\
(117.95)^{* * *}\end{array}$ \\
\hline Industry Dummies & Yes & Yes \\
\hline Year Dummies & Yes & Yes \\
\hline Observations & 13033 & 13033 \\
\hline R-squared & 0.7318 & 0.7327 \\
\hline
\end{tabular}


Panel B: Summary of Direct and Indirect Impact of CSR on Stock Return Volatility based on One-Year Lagged CSR

\begin{tabular}{|c|c|c|c|c|c|}
\hline & \multicolumn{2}{|c|}{ PCTINSTI } & & & \\
\hline & Direct & Indirect & & & \\
\hline CSRIDX_C (t-1) & 0.01051 & -0.00122 & & & \\
\hline \multirow[t]{3}{*}{ CSRIDX_C2 (t-1) } & 0.00030 & $0.00259 * * *$ & & & \\
\hline & & $\mathrm{BNK}$ & INS & INVIIA & MISC \\
\hline & Direct & Indirect & Indirect & Indirect & Indirect \\
\hline CSRIDX_C (t-1) & 0.01091 & $-0.00164 * * *$ & -0.00001 & -0.00011 & 0.00006 \\
\hline CSRIDX_C2 $(\mathrm{t}-1)$ & -0.00042 & $0.00134 * * *$ & 0.00004 & $0.00074 * *$ & $0.00121 * *$ \\
\hline
\end{tabular}

See Appendices A and B for variable definitions. ***, **, and * indicate two-tailed significance at 1\%, 5\%, and $10 \%$ level, respectively. 
Table 7. Results Based on Two-Year Lagged CSR

Panel A: Impact of CSR on Institutional Ownership

\begin{tabular}{lcc}
\hline & PCTINSTI & PCTINSTI \\
\hline CSRIDX(t-2) & -0.0082 & \\
& $(0.74)$ & 0.0096 \\
CSRIDX_C(t-2) & & $(0.79)$ \\
& & -0.0912 \\
CSRIDX_C2(t-2) & & $(3.13)^{* * *}$ \\
Constant & 0.3541 & 0.3568 \\
& $(7.91)^{* * *}$ & $(7.83)^{* * *}$ \\
Control variables & Yes & Yes \\
Industry Dummies & Yes & Yes \\
Year Dummies & Yes & Yes \\
Observations & 13033 & 13033 \\
R-squared & 0.3108 & 0.3123 \\
\hline
\end{tabular}

Panel B: Impact of CSR on Holdings by Various Institution Types

\begin{tabular}{|c|c|c|c|c|c|c|c|c|}
\hline & $\mathrm{BNK}$ & $\mathrm{BNK}$ & INS & INS & INVIIA & INVIIA & MISC & MISC \\
\hline CSRIDX(t-2) & $\begin{array}{c}0.0031 \\
(1.03)\end{array}$ & & $\begin{array}{c}-0.0003 \\
(0.18)\end{array}$ & & $\begin{array}{c}-0.0129 \\
(1.44)\end{array}$ & & $\begin{array}{c}-0.0026 \\
(1.57)\end{array}$ & \\
\hline CSRIDX_C(t-2) & & $\begin{array}{c}0.0070 \\
(1.98)^{* *}\end{array}$ & & $\begin{array}{c}0.0012 \\
(0.66)\end{array}$ & & $\begin{array}{c}-0.0016 \\
(0.17)\end{array}$ & & $\begin{array}{c}-0.0005 \\
(0.26)\end{array}$ \\
\hline CSRIDX_C2(t-2) & & $\begin{array}{l}-0.0201 \\
(2.44)^{* *}\end{array}$ & & $\begin{array}{c}-0.0077 \\
(1.62)\end{array}$ & & $\begin{array}{l}-0.0575 \\
(2.46)^{* *}\end{array}$ & & $\begin{array}{c}-0.0108 \\
(2.44)^{* *}\end{array}$ \\
\hline Constant & $\begin{array}{c}0.0556 \\
(3.97)^{* * *}\end{array}$ & $\begin{array}{c}0.0581 \\
(4.07)^{* * *}\end{array}$ & $\begin{array}{c}0.0185 \\
(2.72)^{* * *}\end{array}$ & $\begin{array}{c}0.0188 \\
(2.79)^{* * *}\end{array}$ & $\begin{array}{c}0.2460 \\
(7.97)^{* * *}\end{array}$ & $\begin{array}{c}0.2447 \\
(7.84)^{* * *}\end{array}$ & $\begin{array}{c}0.0026 \\
(0.43)\end{array}$ & $\begin{array}{c}0.0023 \\
(0.37)\end{array}$ \\
\hline Control variables & Yes & Yes & Yes & Yes & Yes & Yes & Yes & Yes \\
\hline Industry Dummies & Yes & Yes & Yes & Yes & Yes & Yes & Yes & Yes \\
\hline Year Dummies & Yes & Yes & Yes & Yes & Yes & Yes & Yes & Yes \\
\hline Observations & 13033 & 13033 & 13033 & 13033 & 13033 & 13033 & 13033 & 13033 \\
\hline R-squared & 0.4483 & 0.4490 & 0.2243 & 0.2247 & 0.4153 & 0.4160 & 0.1716 & 0.1722 \\
\hline
\end{tabular}


Panel C: Regression of Stock Return Volatility on Institutional Ownership and CSR Activity

\begin{tabular}{lcc}
\hline & DEVRET $(\mathrm{t}+1)$ & DEVRET $(\mathrm{t}+1)$ \\
\hline PCTINSTI & -0.1016 & \\
& $(7.09)^{* * *}$ & -0.2732 \\
BNK & & $(5.46)^{* * *}$ \\
& & -0.1014 \\
INS & & $(1.23)$ \\
& & -0.0122 \\
INVIIA & & $(2.71)^{* * *}$ \\
& & -0.4201 \\
MISC & & $(5.73)^{* * *}$ \\
& & 0.0213 \\
CSRIDX_C(t-2) & 0.0242 & $(2.05)^{* *}$ \\
& $(2.24)^{* *}$ & -0.031 \\
CSRIDX_C2(t-2) & 0.0101 & $(1.22)$ \\
& $(0.35)$ & -3.4208 \\
Constant & -3.5058 & $(119.13)^{* * *}$ \\
& $(117.34)^{* * *}$ & Yes \\
Control variables & Yes & Yes \\
Industry Dummies & Yes & Yes \\
Year Dummies & Yes & 13033 \\
Observations & 13033 & 0.7407 \\
R-squared & 0.7319 & \\
\hline
\end{tabular}

Panel D: Summary of Direct and Indirect Impact of CSR on Stock Return Volatility Based on Two-Year Lagged CSR

\begin{tabular}{lccccc}
\hline & \multicolumn{2}{c}{ PCTINSTI } & & & \\
& Direct & Indirect & & & \\
CSRIDX_C (t-2) & $0.0137 * *$ & -0.0006 & & & \\
CSRIDX_C2 (t-2) & 0.0023 & $0.0021 * * *$ & & & \\
& & & & & \\
& & BNK & INS & INVIIA & MISC \\
& Direct & Indirect & Indirect & Indirect & Indirect \\
\hline CSRIDX_C (t-2) & $0.0121 * *$ & $-0.0011^{* *}$ & -0.0001 & 0.00001 & 0.0001 \\
CSRIDX_C2 (t-2) & -0.0079 & $0.0013^{* *}$ & 0.0002 & $0.0002 * *$ & $0.0010^{* *}$ \\
\hline
\end{tabular}

In this table, CSR variables are measured for year $\mathrm{t}-2$, where year $\mathrm{t}$ is the year that institutional ownership is measured. See Appendix A for other variable definitions. ***, **, and * indicate two-tailed significance at 1\%, $5 \%$, and $10 \%$ level, respectively. 
Table 8. Test of Reverse Causality

Panel A: Regression of CSR on Institutional Ownership

\begin{tabular}{lcc}
\hline & CSRIDX_C & CSRIDX_C \\
\hline PCTINSTI(t-1) & -0.0533 & \\
& $(1.00)$ & -0.0467 \\
PCTINSTI(t-2) & & $(1.18)$ \\
& & -0.0161 \\
ROA & -0.0147 & $(0.39)$ \\
DEVRET & $(0.36)$ & -0.3819 \\
& -0.3927 & $(0.82)$ \\
MKTBK & $(0.84)$ & 0.0131 \\
& 0.0129 & $(2.94)^{* * *}$ \\
RNDR & $(2.93)^{* * *}$ & 0.0108 \\
& 0.0104 & $(0.26)$ \\
LOGASSET & $(0.25)$ & 0.0328 \\
SEGMENTS & 0.0326 & $(3.00)^{* * *}$ \\
& $(2.98)^{* * *}$ & -0.0007 \\
LOGANALYST & -0.0007 & $(0.82)$ \\
& $(0.82)$ & 0.0129 \\
HHI & 0.0133 & $(1.91)^{*}$ \\
DEBTR & $(1.98)^{* *}$ & -0.5476 \\
& -0.5511 & $(1.21)$ \\
CASHFLOW & $(1.21)$ & -0.0750 \\
MEDIANCSR & -0.0749 & $(3.09)^{* * * *}$ \\
& $(3.07)^{* * * *}$ & 0.2345 \\
Constant & 0.2341 & $(4.18)^{* * * *}$ \\
& $(4.21)^{* * *}$ & 0.0068 \\
Industry Dummies & 0.0067 & $(0.89)$ \\
Year Dummies & $(0.88)$ & 0.2374 \\
Observations & 0.2421 & $(2.55)^{* *}$ \\
R-squared & $(2.59)^{* * *}$ & Yes \\
\hline
\end{tabular}


Panel A (Continue)

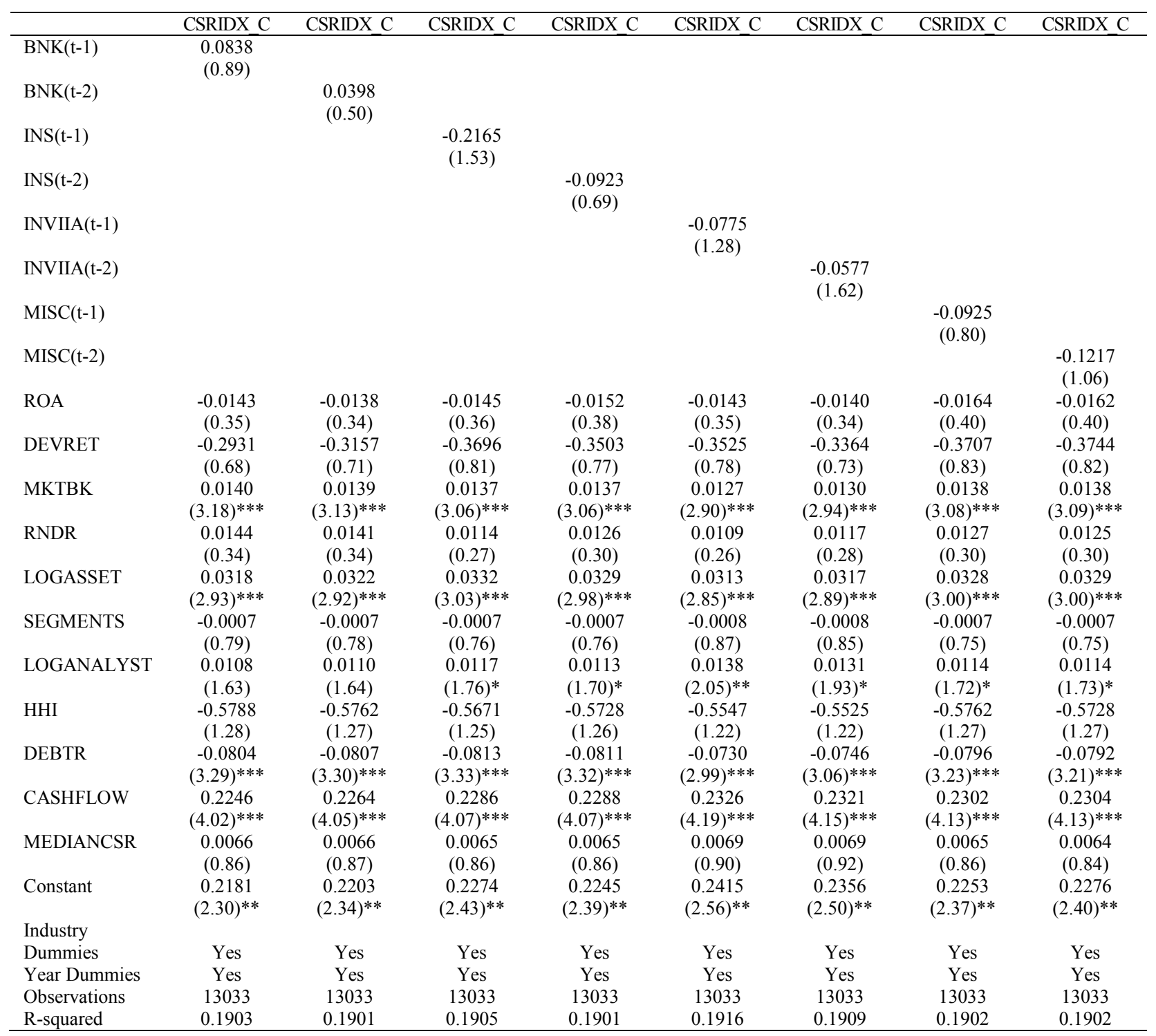


Panel B: Regression of Institutional Ownership on Stock Return Volatility

\begin{tabular}{|c|c|c|}
\hline & PCTINSTI $(t+1)$ & PCTINSTI $(\mathrm{t}+1)$ \\
\hline DEVRET & $\begin{array}{l}0.1259 \\
(0.63)\end{array}$ & \\
\hline $\operatorname{DEVRET}(\mathrm{t}-1)$ & & $\begin{array}{c}0.0170 \\
(1.51)\end{array}$ \\
\hline CSRIDX_C & $\begin{array}{l}0.0262 \\
(1.92)^{*}\end{array}$ & $\begin{array}{l}0.0238 \\
(1.73)^{*}\end{array}$ \\
\hline CSRIDX_C2 & $\begin{array}{c}-0.1130 \\
(4.06)^{* * *}\end{array}$ & $\begin{array}{c}-0.1096 \\
(3.87)^{* * *}\end{array}$ \\
\hline MRET & $\begin{array}{c}0.0164 \\
(3.68)^{* * *}\end{array}$ & $\begin{array}{c}0.0154 \\
(3.49)^{* * *}\end{array}$ \\
\hline TVOL & $\begin{array}{c}0.0421 \\
(7.43)^{* * *}\end{array}$ & $\begin{array}{c}0.0427 \\
(7.41)^{* * *}\end{array}$ \\
\hline BETA & $\begin{array}{l}-0.0289 \\
(2.17)^{* *}\end{array}$ & $\begin{array}{c}0.0029 \\
(0.26)\end{array}$ \\
\hline IRISK & $\begin{array}{c}-5.8767 \\
(6.26)^{* * *}\end{array}$ & $\begin{array}{c}-2.7593 \\
(7.24)^{* * *}\end{array}$ \\
\hline MKRTVAL & $\begin{array}{c}0.0310 \\
(5.46)^{* * *}\end{array}$ & $\begin{array}{c}0.0299 \\
(5.19)^{* * *}\end{array}$ \\
\hline DEBTR & $\begin{array}{c}0.1510 \\
(6.88)^{* * *}\end{array}$ & $\begin{array}{c}0.1483 \\
(6.66)^{* * *}\end{array}$ \\
\hline EP & $\begin{array}{l}0.0524 \\
(1.83)^{*}\end{array}$ & $\begin{array}{c}0.0761 \\
(2.84)^{* * *}\end{array}$ \\
\hline BP & $\begin{array}{c}0.0540 \\
(5.20)^{* * *}\end{array}$ & $\begin{array}{c}0.0522 \\
(5.18)^{* * *}\end{array}$ \\
\hline DP & $\begin{array}{c}-1.0331 \\
(4.89)^{* * *}\end{array}$ & $\begin{array}{c}-1.0654 \\
(4.83)^{* * *}\end{array}$ \\
\hline SALEGRW & $\begin{array}{c}-0.0256 \\
(2.74)^{* * *}\end{array}$ & $\begin{array}{c}-0.0247 \\
(2.77)^{* * *}\end{array}$ \\
\hline SP500 & $\begin{array}{c}0.0456 \\
(4.79)^{* * *}\end{array}$ & $\begin{array}{c}0.0463 \\
(4.83)^{* * *}\end{array}$ \\
\hline SPRATING & $\begin{array}{c}-0.0010 \\
(0.51)\end{array}$ & $\begin{array}{c}-0.0017 \\
(0.83)\end{array}$ \\
\hline SHROUT & $\begin{array}{c}-0.0444 \\
(6.63)^{* * *}\end{array}$ & $\begin{array}{c}-0.0447 \\
(6.67) * * *\end{array}$ \\
\hline FIRMAGE & $\begin{array}{c}0.0002 \\
(1.29)\end{array}$ & $\begin{array}{c}0.0002 \\
(1.14)\end{array}$ \\
\hline CEPS & $\begin{array}{c}-0.0122 \\
(0.43)\end{array}$ & $\begin{array}{c}-0.0260 \\
(1.01)\end{array}$ \\
\hline RNDR & $\begin{array}{c}-0.0623 \\
(2.80)^{* * *}\end{array}$ & $\begin{array}{c}-0.0646 \\
(2.95)^{* * *}\end{array}$ \\
\hline Constant & $\begin{array}{c}0.9655 \\
(7.15)^{* * *}\end{array}$ & $\begin{array}{c}0.4447 \\
(6.87)^{* * *}\end{array}$ \\
\hline Industry Dummies & Yes & Yes \\
\hline Year Dummies & Yes & Yes \\
\hline Observations & 13033 & 13033 \\
\hline R-squared & 0.2933 & 0.2890 \\
\hline
\end{tabular}


Panel B (Continue)

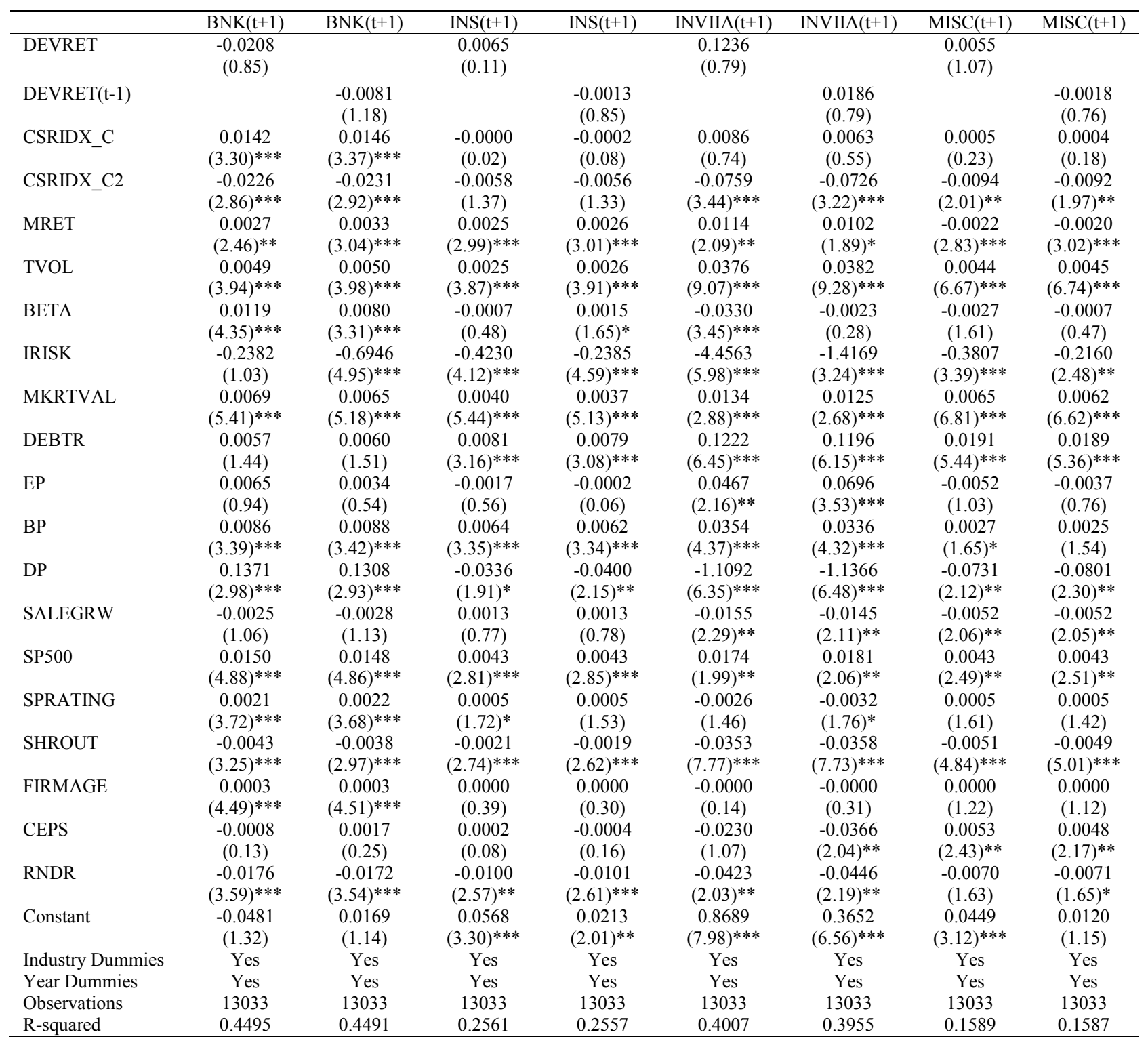

In this table, institutional ownership variables are measured for year $\mathrm{t}-1$ and year $\mathrm{t}-2$ in Panel $\mathrm{A}$ and for year $\mathrm{t}+1$ in Panel B. CSR variables are measured for year t. DEVRET is stock return volatility for year $t$ and DEVRET(t-1) is stock return volatility for year $\mathrm{t}-1$. See Appendices A, B, and C for other variable definitions. ${ }^{* *},{ }^{* *}$, and * indicate two-tailed significance at $1 \%, 5 \%$, and $10 \%$ level, respectively. 
Table 9 Change Specification

Panel A: Regression of Changes in Institutional Ownership on Changes in CSR

\begin{tabular}{|c|c|c|c|c|c|}
\hline & $\triangle$ PCTINSTI & $\triangle \mathrm{BNK}$ & $\Delta \mathrm{INS}$ & $\Delta$ INVIIA & $\Delta \mathrm{MISC}$ \\
\hline \multirow[t]{2}{*}{$\Delta$ CSRIDX_C (t-1) } & 0.0034 & 0.0058 & 0.0004 & -0.0022 & 0.00003 \\
\hline & $(0.67)$ & $(2.96)^{* * *}$ & $(0.32)$ & $(0.46)$ & $(0.03)$ \\
\hline \multirow[t]{2}{*}{$\Delta$ CSRIDX_C2 (t-1) } & -0.0112 & -0.0040 & -0.0021 & -0.0175 & 0.0040 \\
\hline & $(2.14)^{* *}$ & $(2.00)^{* *}$ & $(0.70)$ & $(1.87)^{*}$ & $(1.59)$ \\
\hline$\triangle \mathrm{MRET}$ & -0.0327 & -0.0073 & $\begin{array}{c}-0.0044 \\
(6.04) * * *\end{array}$ & -0.0193 & -0.0013 \\
\hline \multirow[t]{2}{*}{$\Delta \mathrm{TVOL}$} & -0.0030 & 0.0013 & -0.0003 & -0.0044 & 0.0002 \\
\hline & $(2.59)^{* * *}$ & $(3.24)^{* * *}$ & $(1.00)$ & $(4.10)^{* * *}$ & $(0.69)$ \\
\hline \multirow[t]{2}{*}{$\triangle$ MKTVAL } & 0.0702 & 0.0145 & 0.0090 & 0.0437 & 0.0029 \\
\hline & $(14.42)^{* * *}$ & $(9.05)^{* * *}$ & $(7.98)^{* * *}$ & $(9.71)^{* * *}$ & $(2.58)^{* *}$ \\
\hline$\triangle \mathrm{BETA}$ & $\begin{array}{l}-0.0057 \\
(1.80)^{*}\end{array}$ & $\begin{array}{l}0.0021 \\
(1.87)^{*}\end{array}$ & $\begin{array}{c}0.0012 \\
(1.54)\end{array}$ & $\begin{array}{c}-0.0109 \\
(3.74)^{* * *}\end{array}$ & $\begin{array}{c}-0.0003 \\
(0.35)\end{array}$ \\
\hline \multirow[t]{2}{*}{$\Delta$ IRISK } & -0.2302 & -0.0084 & -0.0060 & -0.0607 & -0.0603 \\
\hline & $(1.11)$ & $(0.13)$ & $(0.14)$ & $(0.32)$ & $(1.28)$ \\
\hline \multirow[t]{2}{*}{$\triangle \mathrm{DEBTR}$} & -0.0186 & -0.0037 & -0.0062 & -0.0103 & 0.0021 \\
\hline & $(1.09)$ & $(0.60)$ & $(1.60)$ & $(0.64)$ & $(0.50)$ \\
\hline \multirow[t]{2}{*}{$\Delta \mathrm{EP}$} & -0.0040 & 0.0091 & 0.0054 & -0.0199 & 0.0040 \\
\hline & $(0.30)$ & $(2.03)^{* *}$ & $(1.94)^{*}$ & $(1.59)$ & $(1.38)$ \\
\hline \multirow[t]{2}{*}{$\Delta \mathrm{BP}$} & 0.0016 & 0.0008 & -0.0019 & 0.0062 & 0.0012 \\
\hline & $(0.24)$ & $(0.37)$ & $(1.33)$ & $(1.00)$ & $(0.73)$ \\
\hline \multirow[t]{2}{*}{$\Delta \mathrm{DP}$} & -0.1286 & 0.0151 & 0.0163 & -0.2796 & 0.0089 \\
\hline & $(1.36)$ & $(0.50)$ & $(0.87)$ & $(3.32)^{* * *}$ & $(0.41)$ \\
\hline \multirow[t]{2}{*}{$\triangle$ SALEGRW } & 0.0106 & -0.0030 & 0.0004 & 0.0131 & 0.0001 \\
\hline & $(2.39)^{* *}$ & $(2.05)^{* *}$ & $(0.42)$ & $(3.24)^{* * *}$ & $(0.12)$ \\
\hline \multirow[t]{2}{*}{$\Delta \mathrm{SP} 500$} & -0.0153 & -0.0007 & -0.0020 & -0.0124 & -0.0007 \\
\hline & $(7.97)^{* * *}$ & $(0.96)$ & $(3.76)^{* * *}$ & $(6.77)^{* * *}$ & $(1.35)$ \\
\hline \multirow[t]{2}{*}{$\Delta$ SHROUT } & -0.0548 & -0.0095 & -0.0052 & -0.0391 & -0.0019 \\
\hline & $(7.99)^{* * *}$ & $(3.92)^{* * *}$ & $(2.92)^{* * *}$ & $(6.27)^{* * *}$ & $(1.22)$ \\
\hline \multirow[t]{2}{*}{$\triangle \mathrm{CEPS}$} & -0.0115 & -0.0051 & -0.0026 & -0.0016 & -0.0048 \\
\hline & $(1.32)$ & $(1.80)^{*}$ & $(1.39)$ & $(0.20)$ & $(2.48)^{* *}$ \\
\hline \multirow[t]{2}{*}{$\triangle \mathrm{RNDR}$} & 0.0196 & -0.0041 & -0.0076 & 0.0443 & 0.0044 \\
\hline & $(0.46)$ & $(0.34)$ & $(0.96)$ & $(1.13)$ & $(0.45)$ \\
\hline \multirow[t]{2}{*}{ Constant } & 0.0894 & -0.0006 & 0.0118 & 0.0601 & 0.0163 \\
\hline & $(10.73)^{* * *}$ & $(0.12)$ & $(3.62)^{* * *}$ & $(8.93)^{* * *}$ & $(6.96)^{* * *}$ \\
\hline Industry Dummies & Yes & Yes & Yes & Yes & Yes \\
\hline Year Dummies & Yes & Yes & Yes & Yes & Yes \\
\hline Observations & 13033 & 13033 & 13033 & 13033 & 13033 \\
\hline R-squared & 0.2260 & 0.3367 & 0.0522 & 0.0997 & 0.1167 \\
\hline
\end{tabular}


Panel B: Regression of Changes in Stock Return Volatility on Changes in Institutional Ownership and Changes in CSR

\begin{tabular}{|c|c|c|}
\hline & $\Delta \operatorname{DEVRET}(\mathrm{t}+1)$ & $\Delta \operatorname{DEVRET}(\mathrm{t}+1)$ \\
\hline$\triangle$ PCTINSTI & $\begin{array}{c}-0.0061 \\
(2.03)^{* *}\end{array}$ & \\
\hline$\triangle \mathrm{BNK}$ & & $\begin{array}{l}-0.0808 \\
(2.58) * *\end{array}$ \\
\hline$\Delta \mathrm{INS}$ & & $\begin{array}{c}0.1279 \\
(0.71)\end{array}$ \\
\hline$\Delta$ INVIIA & & $\begin{array}{l}-0.0086 \\
(2.39)^{* *}\end{array}$ \\
\hline$\Delta \mathrm{MISC}$ & & $\begin{array}{c}-0.2429 \\
(3.10)^{* * *}\end{array}$ \\
\hline$\Delta$ CSRIDX_C (t-1) & $\begin{array}{c}-0.0060 \\
(0.56)\end{array}$ & $\begin{array}{c}-0.0061 \\
(0.59)\end{array}$ \\
\hline$\Delta$ CSRIDX_C2 (t-1) & $\begin{array}{c}0.0082 \\
(0.35)\end{array}$ & $\begin{array}{c}0.0086 \\
(0.36)\end{array}$ \\
\hline$\triangle \mathrm{MRET}$ & $\begin{array}{l}0.0085 \\
(1.69)^{*}\end{array}$ & $\begin{array}{l}0.0091 \\
(1.81)^{*}\end{array}$ \\
\hline$\triangle \mathrm{TVOL}$ & $\begin{array}{c}-0.0005 \\
(0.20)\end{array}$ & $\begin{array}{c}-0.0005 \\
(0.22)\end{array}$ \\
\hline$\triangle \mathrm{MKTVAL}$ & $\begin{array}{l}-0.0115 \\
(1.29)\end{array}$ & $\begin{array}{c}-0.0126 \\
(1.41)\end{array}$ \\
\hline$\triangle \mathrm{DEBTR}$ & $\begin{array}{c}0.0976 \\
(2.91)^{* * *}\end{array}$ & $\begin{array}{c}0.0990 \\
(2.96)^{* * *}\end{array}$ \\
\hline$\Delta \mathrm{EP}$ & $\begin{array}{c}-0.2190 \\
(10.20)^{* * *}\end{array}$ & $\begin{array}{c}-0.2195 \\
(10.22)^{* * *}\end{array}$ \\
\hline$\Delta \mathrm{BP}$ & $\begin{array}{c}0.0243 \\
(2.14)^{* *}\end{array}$ & $\begin{array}{c}0.0247 \\
(2.18)^{* *}\end{array}$ \\
\hline$\Delta \mathrm{DP}$ & $\begin{array}{c}1.2323 \\
(7.28)^{* * *}\end{array}$ & $\begin{array}{c}1.2286 \\
(7.26)^{* * *}\end{array}$ \\
\hline$\triangle$ SALEGRW & $\begin{array}{l}-0.0115 \\
(1.39)\end{array}$ & $\begin{array}{c}-0.0112 \\
(1.36)\end{array}$ \\
\hline$\Delta \mathrm{SP} 500$ & $\begin{array}{c}0.0002 \\
(0.05)\end{array}$ & $\begin{array}{c}0.0002 \\
(0.05)\end{array}$ \\
\hline$\triangle$ SHROUT & $\begin{array}{l}0.0027 \\
(0.19)\end{array}$ & $\begin{array}{c}0.0031 \\
(0.22)\end{array}$ \\
\hline$\triangle \mathrm{CEPS}$ & $\begin{array}{c}0.0584 \\
(4.20)^{* * *}\end{array}$ & $\begin{array}{c}0.0578 \\
(4.16)^{* * *}\end{array}$ \\
\hline$\triangle \mathrm{RNDR}$ & $\begin{array}{c}0.0394 \\
(0.53)\end{array}$ & $\begin{array}{l}0.0422 \\
(0.57)\end{array}$ \\
\hline Constant & $\begin{array}{c}-0.0805 \\
(3.74)^{* * *}\end{array}$ & $\begin{array}{c}-0.0862 \\
(3.99)^{* * *}\end{array}$ \\
\hline Industry Dummies & Yes & Yes \\
\hline Year Dummies & Yes & Yes \\
\hline Observations & 13033 & 13033 \\
\hline R-squared & 0.6515 & 0.6519 \\
\hline
\end{tabular}


Panel C: Summary of Direct and Indirect Impact of CSR on Stock Return Volatility

\begin{tabular}{lccccc}
\hline \multicolumn{4}{c}{$\Delta$ PCTINSTI } & & \\
\cline { 1 - 3 } & Direct & Indirect & & \\
\cline { 1 - 3 }$\Delta$ CSRIDX_C & -0.003305 & -0.000011 & & \\
& 0.002013 & $0.000017^{* *}$ & & & \\
& & & & & \\
& & & & & \\
& Direct & Indirect & Indirect & Indirect & Indirect \\
\hline$\Delta$ CSRIDX_C & -0.003360 & $-0.000258^{* *}$ & 0.000028 & 0.000010 & -0.0000431 \\
$\Delta$ CSRIDX_C2 & 0.002111 & $0.000079^{* *}$ & -0.000066 & $0.000037^{*}$ & -0.000239 \\
\hline
\end{tabular}

Changes in CSR are changes from t-3 to t-1. Changes in institutional ownership and changes in control variables are changes from $\mathrm{t}-1$ to $t$. Changes in DEVRET are changes from $\mathrm{t}$ to $\mathrm{t}+1 .{ }^{* * *},{ }^{* *}$, and * indicate two-tailed significance at $1 \%, 5 \%$, and $10 \%$ level, respectively. 
Table 10 The Impact of CSR and Institutional Ownership on Stock Return Volatility through the Interaction of CSR Index and Institutional Ownership

Panel A: Levels of CSR Index, Institutional Ownership, and Stock Return Volatility

\begin{tabular}{|c|c|c|c|c|}
\hline & $\operatorname{DEVRET}(\mathrm{t}+1)$ & $\operatorname{DEVRET}(\mathrm{t}+1)$ & DEVRET $(\mathrm{t}+1)$ & $\operatorname{DEVRET}(\mathrm{t}+1)$ \\
\hline PCTINSTI & $\begin{array}{c}-0.0749 \\
(4.32)^{* * *}\end{array}$ & $\begin{array}{c}-0.0770 \\
(4.41)^{* * *}\end{array}$ & & \\
\hline $\mathrm{BNK}$ & & & $\begin{array}{c}-0.2831 \\
(4.83)^{* * *}\end{array}$ & $\begin{array}{c}-0.3049 \\
(5.19) * * *\end{array}$ \\
\hline INS & & & $\begin{array}{c}-0.1961 \\
(0.51)\end{array}$ & $\begin{array}{c}-0.2343 \\
(0.33)\end{array}$ \\
\hline INVIIA & & & $\begin{array}{c}-0.0107 \\
(1.99)^{* *}\end{array}$ & $\begin{array}{c}-0.0068 \\
(2.39)^{* *}\end{array}$ \\
\hline MISC & & & $\begin{array}{c}-0.3732 \\
(4.12)^{* * *}\end{array}$ & $\begin{array}{c}-0.4293 \\
(4.80)^{* * *}\end{array}$ \\
\hline CSRIDX_C(t-1) x PCTINSTI & $\begin{array}{c}-0.0263 \\
(0.42)\end{array}$ & & & \\
\hline CSRIDX_C2(t-1) x PCTINSTI & $\begin{array}{l}0.0157 \\
(0.10)\end{array}$ & & & \\
\hline CSRIDX_C(t-2) x PCTINSTI & & $\begin{array}{c}-0.0580 \\
(0.99)\end{array}$ & & \\
\hline CSRIDX_C2(t-2) x PCTINSTI & & $\begin{array}{c}0.0422 \\
(0.26)\end{array}$ & & \\
\hline CSRIDX_C(t-1) x BNK & & & $\begin{array}{l}0.2357 \\
(1.19)\end{array}$ & \\
\hline CSRIDX_C2(t-1) x BNK & & & $\begin{array}{c}-0.1071 \\
(0.22)\end{array}$ & \\
\hline CSRIDX_C(t-1) x INS & & & $\begin{array}{l}0.1317 \\
(0.40)\end{array}$ & \\
\hline CSRIDX_C2(t-1) $x$ INS & & & $\begin{array}{l}1.0631 \\
(1.30)\end{array}$ & \\
\hline CSRIDX_C(t-1) x INVIIA & & & $\begin{array}{c}-0.1042 \\
(1.49)\end{array}$ & \\
\hline CSRIDX_C2(t-1) x INVIIA & & & $\begin{array}{l}0.0195 \\
(0.11)\end{array}$ & \\
\hline CSRIDX_C(t-1) x MISC & & & $\begin{array}{l}0.0027 \\
(0.01)\end{array}$ & \\
\hline CSRIDX_C2(t-1) x MISC & & & $\begin{array}{c}-0.6180 \\
(0.83)\end{array}$ & \\
\hline CSRIDX_C(t-2) x BNK & & & & $\begin{array}{c}-0.1138 \\
(0.65)\end{array}$ \\
\hline CSRIDX_C2(t-2) x BNK & & & & $\begin{array}{c}0.4966 \\
(1.04)\end{array}$ \\
\hline CSRIDX_C(t-2) x INS & & & & $\begin{array}{c}-0.0573 \\
(0.18)\end{array}$ \\
\hline CSRIDX_C2(t-2) $x$ INS & & & & $\begin{array}{l}1.7950 \\
(1.12)\end{array}$ \\
\hline CSRIDX_C(t-2) x INVIIA & & & & $\begin{array}{l}-0.1105 \\
(1.73)^{*}\end{array}$ \\
\hline CSRIDX_C2(t-2) x INVIIA & & & & $\begin{array}{c}-0.0978 \\
(0.40)\end{array}$ \\
\hline CSRIDX_C(t-2) x MISC & & & & $\begin{array}{c}-0.1605 \\
(0.73)\end{array}$ \\
\hline CSRIDX_C2(t-2) x MISC & & & & $\begin{array}{l}0.1664 \\
(0.22)\end{array}$ \\
\hline CSRIDX_C(t-1) & $\begin{array}{c}0.0330 \\
(0.71)\end{array}$ & & $\begin{array}{c}0.0294 \\
(0.57)\end{array}$ & \\
\hline CSRIDX_C2(t-1) & $\begin{array}{c}-0.0320 \\
(0.27)\end{array}$ & & $\begin{array}{c}-0.0412 \\
(0.32)\end{array}$ & \\
\hline CSRIDX_C(t-2) & & $\begin{array}{c}0.0606 \\
(1.41)\end{array}$ & & $\begin{array}{c}0.0972 \\
(2.10)^{* *}\end{array}$ \\
\hline CSRIDX_C2(t-2) & & $\begin{array}{c}-0.0592 \\
(0.49)\end{array}$ & & $\begin{array}{c}-0.1577 \\
(1.22)\end{array}$ \\
\hline MRET & $\begin{array}{c}0.0543 \\
(7.42)^{* * *}\end{array}$ & $\begin{array}{c}0.0543 \\
(7.43)^{* * *}\end{array}$ & $\begin{array}{c}0.0539 \\
(7.36)^{* * *}\end{array}$ & $\begin{array}{c}0.0538 \\
(7.35)^{* * *}\end{array}$ \\
\hline
\end{tabular}




\begin{tabular}{|c|c|c|c|c|}
\hline TVOL & $\begin{array}{c}0.0663 \\
(22.55)^{* * *}\end{array}$ & $\begin{array}{c}0.0662 \\
(22.50)^{* * *}\end{array}$ & $\begin{array}{c}0.0667 \\
(22.57)^{* * *}\end{array}$ & $\begin{array}{c}0.0663 \\
(22.45)^{* * *}\end{array}$ \\
\hline MKTVAL & $\begin{array}{c}-0.1637 \\
(41.38)^{* * *}\end{array}$ & $\begin{array}{c}-0.1639 \\
(41.52)^{* * *}\end{array}$ & $\begin{array}{c}-0.1602 \\
(40.02)^{* * *}\end{array}$ & $\begin{array}{c}-0.1606 \\
(40.27)^{* * * *}\end{array}$ \\
\hline DEBTR & $\begin{array}{c}-0.0207 \\
(1.44)\end{array}$ & $\begin{array}{c}-0.0205 \\
(1.43)\end{array}$ & $\begin{array}{c}-0.0199 \\
(1.39)\end{array}$ & $\begin{array}{c}-0.0206 \\
(1.43)\end{array}$ \\
\hline EP & $\begin{array}{c}-0.3847 \\
(13.36)^{* * *}\end{array}$ & $\begin{array}{c}-0.3839 \\
(13.34)^{* * *}\end{array}$ & $\begin{array}{c}-0.3807 \\
(13.21)^{* * *}\end{array}$ & $\begin{array}{c}-0.3796 \\
(13.18)^{* * *}\end{array}$ \\
\hline BP & $\begin{array}{c}0.0210 \\
(2.45)^{* *}\end{array}$ & $\begin{array}{c}0.0209 \\
(2.44)^{* *}\end{array}$ & $\begin{array}{c}0.0221 \\
(2.57)^{* *}\end{array}$ & $\begin{array}{c}0.0213 \\
(2.48)^{* *}\end{array}$ \\
\hline DP & $\begin{array}{c}-2.3548 \\
(15.63)^{* * *}\end{array}$ & $\begin{array}{c}-2.3536 \\
(15.62)^{* * *}\end{array}$ & $\begin{array}{c}-2.2755 \\
(14.95)^{* * *}\end{array}$ & $\begin{array}{c}-2.2761 \\
(14.95)^{* * * *}\end{array}$ \\
\hline SALEGRW & $\begin{array}{c}0.1148 \\
(8.59)^{* * *}\end{array}$ & $\begin{array}{c}0.1151 \\
(8.61)^{* * *}\end{array}$ & $\begin{array}{c}0.1109 \\
(8.30)^{* * *}\end{array}$ & $\begin{array}{c}0.1114 \\
(8.34)^{* * *}\end{array}$ \\
\hline SP500 & $\begin{array}{c}0.0180 \\
(2.60) * * *\end{array}$ & $\begin{array}{c}0.0184 \\
(2.67)^{* * *}\end{array}$ & $\begin{array}{c}0.0222 \\
(3.18)^{* * *}\end{array}$ & $\begin{array}{c}0.0231 \\
(3.32)^{* * *}\end{array}$ \\
\hline SPRATING & $\begin{array}{c}-0.0215 \\
(14.89)^{* * *}\end{array}$ & $\begin{array}{c}-0.0216 \\
(14.91)^{* * *}\end{array}$ & $\begin{array}{c}-0.0208 \\
(14.43)^{* * *}\end{array}$ & $\begin{array}{c}-0.0208 \\
(14.45)^{* * *}\end{array}$ \\
\hline SHROUT & $\begin{array}{c}0.1189 \\
(27.03)^{* * *}\end{array}$ & $\begin{array}{c}0.1190 \\
(27.04)^{* * *}\end{array}$ & $\begin{array}{c}0.1180 \\
(26.74)^{* * *}\end{array}$ & $\begin{array}{c}0.1182 \\
(26.79)^{* * *}\end{array}$ \\
\hline FIRMAGE & $\begin{array}{c}-0.0007 \\
(5.24)^{* * *}\end{array}$ & $\begin{array}{c}-0.0007 \\
(5.24)^{* * *}\end{array}$ & $\begin{array}{c}-0.0006 \\
(4.67)^{* * *}\end{array}$ & $\begin{array}{c}-0.0006 \\
(4.73)^{* * *}\end{array}$ \\
\hline CEPS & $\begin{array}{c}0.2061 \\
(8.24)^{* * *}\end{array}$ & $\begin{array}{c}0.2056 \\
(8.22)^{* * *}\end{array}$ & $\begin{array}{c}0.2083 \\
(8.28)^{* * *}\end{array}$ & $\begin{array}{c}0.2074 \\
(8.24)^{* * *}\end{array}$ \\
\hline RNDR & $\begin{array}{l}0.0135 \\
(0.58)\end{array}$ & $\begin{array}{l}0.0141 \\
(0.61)\end{array}$ & $\begin{array}{c}0.0075 \\
(0.33)\end{array}$ & $\begin{array}{c}0.0096 \\
(0.41)\end{array}$ \\
\hline Constant & $\begin{array}{c}-3.4128 \\
(119.97)^{* * *}\end{array}$ & $\begin{array}{c}-3.4092 \\
(119.05)^{* * *}\end{array}$ & $\begin{array}{c}-3.4247 \\
(120.05)^{* * *}\end{array}$ & $\begin{array}{c}-3.4145 \\
(118.98)^{* * *}\end{array}$ \\
\hline Industry Dummies & Yes & Yes & Yes & Yes \\
\hline Year Dummies & Yes & Yes & Yes & Yes \\
\hline Observations & 13033 & 13033 & 13033 & 13033 \\
\hline R-squared & 0.7397 & 0.7398 & 0.7409 & 0.7410 \\
\hline
\end{tabular}


Panel B: Changes of CSR Index, Institutional Ownership, and Stock Return Volatility

\begin{tabular}{|c|c|c|}
\hline & $\Delta \operatorname{DEVRET}(\mathrm{t}+1)$ & $\Delta \operatorname{DEVRET}(\mathrm{t}+1)$ \\
\hline$\Delta$ PCTINSTI & $\begin{array}{c}0.0006 \\
(0.03)\end{array}$ & \\
\hline$\triangle \mathrm{BNK}$ & & $\begin{array}{c}-0.0737 \\
(1.42)\end{array}$ \\
\hline$\Delta \mathrm{INS}$ & & $\begin{array}{c}0.1017 \\
(1.30)\end{array}$ \\
\hline$\Delta$ INVIIA & & $\begin{array}{c}-0.0074 \\
(1.30)\end{array}$ \\
\hline$\Delta \mathrm{MISC}$ & & $\begin{array}{c}-0.2307 \\
(2.71)^{* * *}\end{array}$ \\
\hline$\Delta$ CSRIDX_C (t-1) x $\Delta$ PCTINSTI & $\begin{array}{c}-0.0005 \\
(0.01)\end{array}$ & \\
\hline$\Delta$ CSRIDX_C2 (t-1) x $\Delta$ PCTINSTI & $\begin{array}{c}0.0299 \\
(0.15)\end{array}$ & \\
\hline$\Delta$ CSRIDX_C (t-1) $\mathrm{x} \Delta \mathrm{BNK}$ & & $\begin{array}{l}0.1317 \\
(0.70)\end{array}$ \\
\hline$\Delta$ CSRIDX_C2 (t-1) $\times \triangle B$ BNK & & $\begin{array}{c}-0.0264 \\
(0.06)\end{array}$ \\
\hline$\Delta$ CSRIDX_C (t-1) $\times \Delta \mathrm{INS}$ & & $\begin{array}{l}0.4766 \\
(1.24)\end{array}$ \\
\hline$\Delta$ CSRIDX_C2 (t-1) $\mathrm{x} \Delta \mathrm{INS}$ & & $\begin{array}{c}-0.8052 \\
(1.23)\end{array}$ \\
\hline$\Delta$ CSRIDX_C (t-1) x $\Delta$ INVIIA & & $\begin{array}{c}-0.0374 \\
(0.35)\end{array}$ \\
\hline$\Delta$ CSRIDX_C2 (t-1) x $\Delta$ INVIIA & & $\begin{array}{c}0.0451 \\
(0.20)\end{array}$ \\
\hline$\Delta$ CSRIDX_C $(\mathrm{t}-1) \mathrm{x} \Delta \mathrm{MISC}$ & & $\begin{array}{c}-0.2122 \\
(0.75)\end{array}$ \\
\hline$\Delta$ CSRIDX_C2 (t-1) $\times \Delta$ MISC & & $\begin{array}{c}-0.0926 \\
(0.15)\end{array}$ \\
\hline$\Delta$ CSRIDX_C (t-1) & $\begin{array}{c}-0.0061 \\
(0.59)\end{array}$ & $\begin{array}{c}-0.0039 \\
(0.36)\end{array}$ \\
\hline$\Delta$ CSRIDX_C2 (t-1) & $\begin{array}{c}0.0082 \\
(0.39)\end{array}$ & $\begin{array}{c}0.0075 \\
(0.35)\end{array}$ \\
\hline$\triangle \mathrm{MRET}$ & $\begin{array}{l}0.0085 \\
(1.56)\end{array}$ & $\begin{array}{l}0.0091 \\
(1.67)^{*}\end{array}$ \\
\hline$\Delta \mathrm{TVOL}$ & $\begin{array}{c}-0.0005 \\
(0.18)\end{array}$ & $\begin{array}{c}-0.0005 \\
(0.19)\end{array}$ \\
\hline$\triangle \mathrm{MKTVAL}$ & $\begin{array}{c}-0.0115 \\
(1.19)\end{array}$ & $\begin{array}{c}-0.0128 \\
(1.31)\end{array}$ \\
\hline$\triangle \mathrm{DEBTR}$ & $\begin{array}{c}0.0976 \\
(2.65)^{* * *}\end{array}$ & $\begin{array}{c}0.0985 \\
(2.67)^{* * *}\end{array}$ \\
\hline$\Delta \mathrm{EP}$ & $\begin{array}{c}-0.2189 \\
(8.62)^{* * *}\end{array}$ & $\begin{array}{c}-0.2191 \\
(8.64)^{* * *}\end{array}$ \\
\hline$\Delta \mathrm{BP}$ & $\begin{array}{c}0.0242 \\
(1.60)\end{array}$ & $\begin{array}{l}0.0245 \\
(1.62)\end{array}$ \\
\hline$\Delta \mathrm{DP}$ & $\begin{array}{c}1.2325 \\
(5.94)^{* * *}\end{array}$ & $\begin{array}{c}1.2303 \\
(5.95)^{* * *}\end{array}$ \\
\hline$\triangle$ SALEGRW & $\begin{array}{c}-0.0115 \\
(1.18)\end{array}$ & $\begin{array}{c}-0.0115 \\
(1.18)\end{array}$ \\
\hline$\Delta \mathrm{SP} 500$ & $\begin{array}{l}0.0002 \\
(0.05)\end{array}$ & $\begin{array}{l}0.0005 \\
(0.10)\end{array}$ \\
\hline$\triangle$ SHROUT & $\begin{array}{l}0.0028 \\
(0.19)\end{array}$ & $\begin{array}{l}0.0028 \\
(0.19)\end{array}$ \\
\hline$\triangle \mathrm{CEPS}$ & $\begin{array}{c}0.0584 \\
(3.87)^{* * *}\end{array}$ & $\begin{array}{c}0.0575 \\
(3.82)^{* * * *}\end{array}$ \\
\hline$\triangle \mathrm{RNDR}$ & 0.0395 & 0.0397 \\
\hline
\end{tabular}


$(0.34)$

Constant

Industry Dummies

Year Dummies

Observations

R-squared
$-0.0805$

$(4.63)^{* * *}$

Yes

Yes

13033

0.6515
$(0.35)$

$-0.0865$

$(4.93)^{* * *}$

Yes

Yes

13033

0.6520

$* * *, * *$, and $*$ indicate two-tailed significance at $1 \%, 5 \%$, and $10 \%$ level, respectively. 